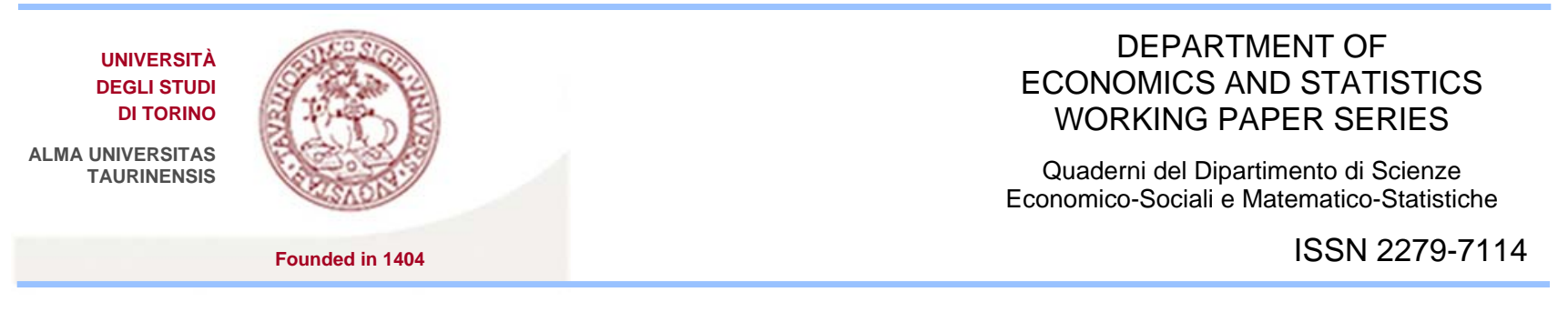

\title{
WORKER FLOWS, REALLOCATION DYNAMICS, AND FIRM PRODUCTIVITY: NEW EVIDENCE FROM LONGITUDINAL MATCHED EMPLOYER-EMPLOYEE DATA
}

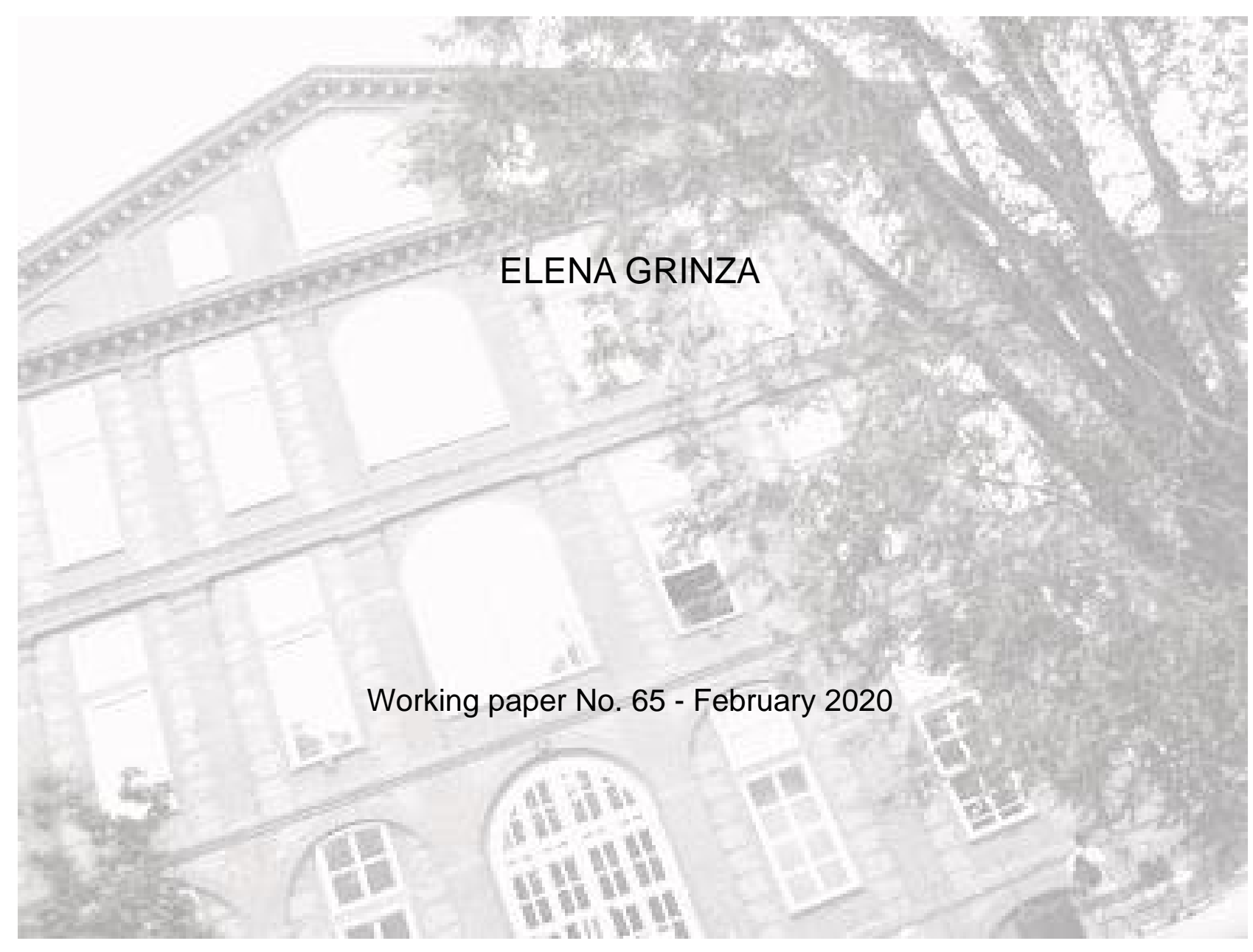




\title{
Worker Flows, Reallocation Dynamics, and Firm Productivity: New Evidence from Longitudinal Matched Employer-Employee Data
}

\author{
Elena Grinza* \\ Department of Management and Production Engineering, Politecnico di Torino \\ Corso Duca degli Abruzzi 24 - 10129, Turin (Italy) \\ Department of Economics and Statistics, University of Turin \\ Corso Unione Sovietica 218/Bis - 10134, Turin (Italy)
}

\begin{abstract}
This paper investigates the impact of a firm's worker flows on productivity by using unique longitudinal matched employer-employee data. The analysis splits the firm's total worker flows into three components: workers' replacements (excess worker flows), hirings meant to increase the firm's employment level (net hirings), and separations of workers intended to decrease the firm's workforce (net separations). This allows isolating the impact of workers' replacements, which represent the most prominent (and compelling) feature of worker mobility. Endogeneity is dealt with by using a modified version of the Ackerberg et al.'s (2015) control function method, which explicitly accounts for firm fixed effects. The main finding is that excess flows foster productivity, and so do net hirings, while net separations hurt it. The effect of excess flows is heterogeneous and varies widely based on the types of replacements, the categories of workers involved, and the types of firms experiencing such flows. Overall, the findings of this paper highlight the importance of reallocation dynamics to reach better employer-employee matches and call for a reconsideration of policies concerning the flexibility of the labor market.
\end{abstract}

Keywords: Worker flows, excess worker flows, firm productivity, semi-parametric estimation of production functions, longitudinal matched employer-employee data.

JEL: J63, D24.

*I am grateful to Francesco Devicienti for his precious support. I thank Cristian Bartolucci, Christopher J. Flinn, Paul Grieco, Reint E. Gropp, Steffen Müller, Ronald L. Oaxaca, Francesco Quatraro, Mariacristina Rossi, François Rycx, Alessandro Sembenelli, Vincent Vandenberghe, and Davide Vannoni for their helpful comments and suggestions. I also thank the participants to the IfW Research Seminars in Economics at the Kiel Institute for the World Economy (Kiel, Germany), the IWH Research Seminars in Economics at the Halle Institute for Economic Research (Halle, Germany), and the 14th Annual Workshop of the Italian Society of Industrial Economics and Policy (Florence, Italy).

E-mail: elena.grinza@polito.it. Telephone: (00 39) 011090 4917. Orcid: orcid.org/0000-0002-8978-634X. 


\section{Introduction}

A ubiquitous feature of labor markets is that workers move extensively in and out of firms (Davis and Haltiwanger, 1999). When firms want to expand their workforce, they hire new workers and experience net inflows of workers. When they want to decrease their workforce, they separate from some of their workers and experience net outflows of workers. However, most of the workers' movements in and out of firms happen "in excess" of job creation or destruction (Burgess et al., 2000a, 2001; Lazear and McCue, 2017). Many a time, firms face simultaneous inflows and outflows of workers. For the most diverse reasons, workers separate from firms, and firms have to replace such separated workers with new workers if they want to maintain a particular job slot.

Inflows and outflows of workers have the potential to affect a firm's productive performance significantly. For instance, inflows of new workers can bring valuable knowledge and networks of connections, but also substantial inefficiencies due to initial learning phases. When workers separate from the firm, the firm might lose relevant (firm-specific) knowledge, but it might also get rid of an under-performing worker. In a nutshell, inflows of workers can configure as more or less productive new employer-employee matches, while outflows of workers can configure as more or less productive dissolved employer-employees matches.

Productive performance is a crucial determinant of sustained and sustainable economic performance. Therefore, understanding whether and how worker flows impact on firm productivity is an essential task for research. In recent years, a small but compelling line of literature has emerged to study the productivity impact of several labor-related issues (e.g., the use of parttime work) through large matched employer-employee or firm-level data (e.g., Devicienti et al., 2018; Garnero et al., 2014; Vandenberghe, 2012). However, the productivity impact of worker flows is still a scarcely explored territory. There exist some studies, from the management literature, on the relationship between worker mobility and (various measures of) organizational performance (e.g., Glebbeek and Bax, 2004; Huselid, 1995; Siebert and Zubanov, 2009). On the one hand, they typically rely on either single-firm case studies or very particular samples that do not allow to obtain a representative picture. On the other hand, they commonly rely on simple OLS estimations that do not allow for any (even tentative) causal interpretation of results.

Also, the extant empirical literature has neglected a crucial aspect. The creation of new matches is necessary when the firm expands its workforce: if the firm wants to grow up, it must hire someone. Similarly, the dissolution of existing matches is necessary when the firm reduces its workforce: if the firm wants to get smaller, it must separate from someone. From the viewpoint of the single firm, net inflows or net outflows represent, therefore, necessary events to reach a given employment level. Conversely, the simultaneous creation and destruction of matches embodied in workers' replacements are, in this sense, not necessary: there is no expansion or contraction of employment in this case. From the perspective of the single firm, therefore, 
workers' replacements represent a genuine reallocation of matches. The fact that, in free labor markets, workers' movements "in excess" of job creation or destruction are so abundant must originate from something different than relatively rare events such as retirements or withdrawals from the labor market. It must be, as theorized by Jovanovic (1979) four decades ago, that replacements happen as the result of a reallocation process of employer-employee combinations aimed at searching for better, more productive matches. That this reallocation process succeeds in this intent remains to be seen. For instance, while new matches (i.e., replacement workers) can be in principle precious for the firm, it must be considered that the dissolution of matches (i.e., separated workers) entails the loss of firm-specific knowledge, which generally takes time and resources to be acquired (Becker, 1964).

In sum, net and excess components of a firm's workers' movements respond to structurally different processes, and this calls for their separate analysis (Burgess et al., 2000a). Not only, isolating excess flows allows gauging the effects of reallocation dynamics, which represent the most prominent (and compelling) feature of worker flows (Centeno and Novo, 2012). Previous works analyzing the relationship between worker mobility and organizational performance have not differentiated between net and excess flows, but only focused on total worker flows (also referred to as "worker turnover"). ${ }^{1}$ The management literature on worker turnover, from which current empirical works draw upon, has developed in parallel with the economics literature on worker flows and has historically not incorporated the concept that net and excess flows are structurally different and deserve separate analyses. On the other hand, it is currently missing an empirical paper studying the productivity impact of worker flows that taps into the economic theory and draws upon this consideration.

This paper contributes to the literature on the productivity effect of worker flows on several fronts. First, it explores the impact of a firm's total inflows and outflows of workers on productivity by splitting the total worker flows into its net and excess components. Second, it uses a large longitudinal matched employer-employee data set. These data, which refer to the Veneto region of Italy and cover the period 1995-2001, are based on administrative records and allow reconstructing a detailed, monthly-level history of a firm's worker flows. Most importantly, they encompass a large part of the population of Veneto workers and firms, thus furnishing a comprehensive view of a self-contained labor market. Third, the paper addresses endogeneity problems,

\footnotetext{
${ }^{1}$ Results for the relationship between worker turnover and firm performance emerging from extant studies are somewhat heterogeneous. Some of them find a negative association (e.g., Huselid, 1995; Siebert and Zubanov, 2009; Ton and Huckman, 2008); others report a non-linear correlation (e.g., Glebbeek and Bax, 2004); others look at (total) hires and quits separately (e.g., Bingley and Westgaard-Nielsen, 2004, who find that quits are associated with increased profits and hires are linked to reduced profits). The bulk of these studies focuses on the association between worker turnover and variables such as customer satisfaction and accounting firm performance indicators. The only exceptions are the studies by Huselid (1995) and Siebert and Zubanov (2009), which focus on firm productivity (i.e., they make use of a production function). For thorough reviews of this literature, see Mawdsley and Somaya (2016) and Shaw (2011).
} 
stemming from unobserved firm heterogeneity and reverse causality, by adopting state-of-the-art econometric methods, namely, a modified version of the Ackerberg et al.'s (2015) control function approach developed by Vandenberghe et al. (2013), which explicitly removes firm fixed effects.

Relatedly, the paper conducts novel moderating analyses aimed at exploring how the impacts of worker flows on productivity differ across several aspects, such as the nature of replacements, the categories of workers moving in and out of the firm, and various firm characteristics that likely moderate the impact, including its technology, location in industrial districts, and age and size. While no study in the literature does so, exploring the differential impacts of worker flows is deemed salient. The many (contrasting) forces behind the impacts of inflows and outflows of workers, especially of reallocation dynamics, are likely to play different importance roles depending on specific contexts. For instance, replacements of workers in small firms may create difficulties in optimally staffing the workforce during job vacancy periods, which might be less problematic in larger firms. Similarly, replacements of high-skilled workers might be a more delicate matter compared to replacements of low-skilled workers, as firm-specific knowledge acquired by the firsts might be relatively more important to the firm (e.g., in leadership roles, the knowledge of the firm's processes and routines is crucial to achieve a sustainable competitive advantage).

Apart from the unique features of the data just mentioned, Veneto represents an excellent case study for three main reasons. First, Veneto is one of the wealthiest and most dynamic regions in Italy, comparable to the other most advanced industrialized countries. During the period under investigation, it was characterized by nearly full-employment (Tattara and Valentini, 2010). Excess worker flows were thus genuinely reflecting a pure reallocation process, rather than dynamics linked to abnormal job destruction in (certain sectors of) the economy. Second, despite common views, Italy has a mobile labor market, on a par with other commonly acknowledged mobile countries such as the UK (Contini et al., 2008). As part of such a national context, Veneto has an even higher degree of labor mobility, thus allowing to grasp more deeply effects and dynamics associated with net and excess worker flows (Tattara and Valentini, 2003). Third, Veneto is characterized by the aggregation of firms into industrial districts (Sforzi, 1989). This makes it possible to assess how net and excess worker flows impact productivity in such a setting; an interesting one as labor market pooling typical of spacial concentration provides constant markets for skills.

The main result of the paper is that the different components of worker flows have differentiated impacts on firm productivity. Consistently with the idea that inflows of workers allow the acquisition of new knowledge, net inflows of workers have a positive effect on productivity. Net separations harm productive performance, coherently with the fact that they entail the loss of (firm-specific) knowledge. Instead, excess flows, that is, workers' replacements, positively affect a firm's productivity. This result supports the idea that reallocation of matches is vital for the 
firm to achieve better, more productive employer-employee combinations. Moreover, the overall positive effect of these reallocation dynamics stems from replacements of those workers who make job-to-job transitions, compatible with voluntary quits, and those who drop out of the sample around the retirement age, compatible with retirements.

While a significant positive (negative) impact emerges for net inflows (net outflows) of workers in all the many categories of workers and firms considered separately in the moderating analyses, excess flows impact productivity in a somewhat differentiated fashion. While excess flows of low-skilled workers positively affect productivity, the estimated impact for high-skilled workers is negative, yet small and not significant. Moreover, the positive impact of reallocation dynamics on high-tech firms and firms belonging to industrial districts is far higher compared to that on low-tech firms and firms located outside industrial districts. Lastly, the positive impact of workers' replacements vanishes for small and young firms, whereas it is large and significant for larger and older firms.

The structure of the rest of the paper is as follows. Section 2 presents the theoretical framework and develops the hypotheses tested in the empirical analysis. Section 3 describes the Veneto case. Section 4 reports definitions and formulas of the worker flow measures used in this paper. Section 5 discusses the empirical model and the identification strategy. Section 6 describes the data, discusses some measurement issues, and presents relevant descriptive statistics. Section 7 presents the results. Finally, Section 8 concludes and draws policy implications of the paper's results.

\section{Theoretical framework and hypotheses development}

\subsection{Worker flows and productivity}

A firm's inflows and outflows of workers can affect its productive performance substantially. The underlying mechanisms are various, but they essentially unfold along with the effects of a variation in the firm's knowledge and skill base due to the modification of existing employer-employee matches. Two notions are crucial to characterize the effects of worker flows on productivity: the notion of firm-specific human capital (Becker, 1964) and the concept of tacit knowledge (Polanyi, 1958, 1966). Firm-specific human capital, acquired by the worker through firm-specific training and on-the-job learning processes, is that particular bundle of competences that is only valuable to the firm (Lazear, 2009). As stated by Dosi and Grazzi (2010), instead, "tacitness refers to the inability by the actor(s) implicated, or even by sophisticated observers, to explicitly articulate the sequences of procedures by which "things are done", problems are solved, behavioural patterns are formed, etc.". Thinking of worker flows as bringers of change in the organizational knowledge and skill base is particularly useful because it allows encompassing a variety of "side" mechanisms. For example, the idea that worker flows also modify the firm's knowledge base by 
affecting its networks of connections, which are known to play a critical role in determining a firm's productive performance (e.g., Broschak, 2004; Shaw et al., 2005; Somaya et al., 2008).

Inflows of workers essentially mean inflows of knowledge. Tacit knowledge about the routines and practices of the origin firms can be precious for the recipient firms. Inflows of new workers can also affect the firm's knowledge base by modifying its networks of connections. For example, new workers may open up to productive forms of collaboration with their sending firms. At the same time, hiring a new employee means the cost of making him/her acquire firm-specific human capital. This cost burdens on the firm both directly, in the form of firm-specific training activities, and indirectly, in the form of low productivity during the (initial phases of the) learning process.

Conversely, outflows of workers mean outflows of knowledge. When a worker separates from the firm, the firm loses its firm-specific human capital and tacit knowledge. As it resides in the mind of the individual and cannot be formalized or communicated, tacit knowledge goes away with the separated worker (Grant, 1996; Nonaka, 1994). However, to the extent that it allows the firm to get rid of an under-performing worker (i.e., a bad match), a worker's separation might as well prove a good thing for the firm. Also, the firm's productive relational capital can deteriorate when a worker separates from the firm. For instance, this happens when the separated worker brings a client relationship to a (destination) competing firm. However, the firm's networks of connections can also benefit from outflows of workers, for example, when the separated worker moves to a client/supplier/competitor and allows for a closer relationship between the two firms (e.g., through joint ventures and other forms of collaborations).

Net worker flows entail flows of workers in only one direction: either a firm is expanding its workforce, thereby experiencing net inflows, or it is contracting its employment level, thereby experiencing net outflows. In other words, in the case of net inflows, the firm experiences the creation of new matches; while, in the case of net outflows, the firm experiences the dissolution of existing matches. The productivity impact of these new (in the case of net inflows) or dissolved (in the case of net outflows) employer-employee matches originates from the combination of the various mechanisms just mentioned relative to inflows or outflows of workers, respectively. Instead, excess flows (i.e., workers' replacements) entail two simultaneous worker flows, one out of the firm, the workers' separations, and one into the firm, the replacement hirings. Said differently, workers' replacements imply that the firm experiences the simultaneous dissolution and constitution of matches. Hence, the productivity impact of excess flows is the result of two different impacts, the one stemming from outflows and the one stemming from inflows of workers. However, in the case of workers' replacements, other considerations come into the picture.

Net hirings or net separations represent, so to say, necessary events for the firm that wants to expand or contract its workforce and stem from the evaluation of firms on their optimal level of employment. Differently, excess flows are the result of an ongoing re-evaluation of matches 
by the firm and by the workers (Burgess et al., 2000a). From the perspective of the firm, excess flows represent a reallocation of matches, and the fact that they are so high, ubiquitous, and extremely persistent within firms suggest that they are the result of an equilibrium phenomenon (Burgess et al., 2000a; Lazear and McCue, 2017). In a seminal paper, Jovanovic (1979) develops a theoretical model pointing to that. In this model, excess flows are the mechanism through which, in a world of imperfect information, employer-employee matches in the firm can be reallocated more efficiently as better information becomes available to the parties. Three assumptions underpin this theory (see Jovanovic, 1979, for details). First, each worker performs different jobs with different productivity levels. Symmetrically, for each job slot, different workers have different productivity levels. Second, employers and workers can bargain over wages on an individual basis and renegotiate the wage contract as better information on the quality of the match becomes available. This allows for a signal of good and poor matches: employers satisfied with the match are willing to pay relatively more than employers who are not. The third assumption is that both workers and employers have imperfect information about the exact location of the most productive match. For a given job slot, workers' heterogeneity in productivity levels, the possibility to bargain over wages according to the quality of the match, and imperfect information make workers and employers engage in the search for optimal matches. From the viewpoint of the firm, the reallocation process embodied in excess flows would be the way to reach better matches as better information becomes available to the parties. In short, reallocation dynamics would improve a firm's productivity by removing poor employer-employee matches, which would justify their widespread existence in the real world.

However, this positive aspect might be reduced or even offset by other mechanisms. For example, recruiting a new replacing worker may not be an easy process. Apart from direct recruitment costs (e.g., those related to job advertisements and interviews), job vacancy periods can impose productivity losses since it may not be easy for the remaining workers to perform the extra job previously done by the separated worker (Hom and Griffeth, 1995).

In sum, the idea that the productivity impact of workers' replacements is simply the sum between the impacts of two worker flows, one out and one into the firm, is limiting if one does not bring into the picture the considerations that workers' replacements stem from reallocation dynamics that all sound like an equilibrium phenomenon, on the one hand, and that excess flows might impose organizational inefficiencies due to job vacancy periods, on the other hand. Moreover, the coexistence of these two opposing mechanisms behind workers' replacements would point to an inverted U-shape impact: some amount of excess flows is beneficial to the firm's productive performance, but too many of them become detrimental. Indeed, the positive effects stemming from reallocation dynamics might emerge up to a certain point. When the firm replaces a massive proportion of its workforce, it is likely that organizational problems caused by job vacancies (and loss of a significant part of firm-specific knowledge) prevail and offset positive 
effects. $^{2}$

Given this articulated theoretical framework, it is arduous to infer a priori whether the overall productivity effects of net inflows, net outflows, and excess flows, respectively, are negative or positive. The numerous mechanisms that can intervene suggest that the resulting overall impacts are not trivial and that they are likely the results of the interplay of many opposing forces. Instead, as regards to excess flows, what one can hypothesize with greater certainty is that they have a curvilinear impact on productivity, of an inverted U-shape. Given the discussion up to here, the first two hypotheses are as follows.

Hypothesis 1: The overall productivity impacts of net inflows, net outflows, and excess flows, respectively, can be either negative or positive depending on which effects prevail.

Hypothesis 2: The impact of excess flows has an inverted U-shape, reflecting that a certain amount of excess flows are beneficial, but too many are harmful.

\subsection{The role of worker- and firm-level characteristics}

The numerous mechanisms at stake in the determination of the productivity impacts of worker flows are likely to play different importance roles depending on a variety of worker- and firm-level aspects, which would result into differentiated impacts. While Section 7 presents results for the differentiated impacts of all the three distinct worker flows (i.e., net inflows, net outflows, and excess flows), the discussion here focuses on excess flows given the emphasis of the paper on reallocation dynamics.

First, except for particular cases such as retirements or (forced) withdrawals from the labor market (e.g., due to health problems), workers' replacements can either be the result of a firm's decision or a worker's decision (Burgess et al., 2000a). Whenever a firm judges the match unsatisfactory, it might decide to dismiss the worker and replace him/her with a new one. Whenever a worker judges the match unsatisfactory, he/she might decide to quit the firm, which will have to replace the quitting worker with a new one. Now, it is likely that the productivity impact of a worker's replacement is different depending on whether the firm has chosen or not to dissolve a match and constitute a new one. However, the resulting impacts are far from being easily predictable. Let us first consider the case of quits. When the worker decides to leave the firm, the firm suffers damage given by the fact that it does not choose to replace him/her (for instance, because it judges the match a good one or because the worker is not easily replaceable). However,

\footnotetext{
${ }^{2}$ After all, the management literature acknowledged this a few decades ago. In contrast with the then-existing management theories predicting adverse effects of labor mobility, Abelson and Baysinger (1984) argued that workers' replacements should be evaluated considering the costs and benefits that they bring to the firm. For instance, they suggested that workers' replacements can be favorable when poor performers voluntarily quit and that dismissing poor performers can be beneficial when productivity increases of the newly hired workers overcompensate for dismissal costs. Consistently, they theorized the existence of a (positive) optimal amount of workers' replacements.
} 
it is also true that a worker that quits the firm might have a poor match with it. Although somewhat dated, the meta-analysis performed by Mc Evoy and Cascio (1987) finds support to this latter circumstance. According to their analysis, poor performers (i.e., those with bad matches) are those far more likely to quit. If this is the case, replacements of quitting workers might lead to productivity enhancements. In the case of dismissals, the picture is likewise intricate. While a firm that chooses to replace (i.e., dismisses) a worker arguably does so to replace a (very) poor match, lengthy bureaucratic procedures associated with dismissals and possible obstructive behaviors of dismissed workers during the notice period might substantially attenuate positive effects. A third possibility, much less frequent, is that the firm replaces a retiring worker. In this case, while the firm does not decide to replace the worker, the firm knows that the retiring worker will leave the firm at a specific point in time well in advance (i.e., a retirement is entirely predictable). Possible organizational problems due to job vacancy periods are thus sharply reduced, and the resulting impact of workers' replacements generated by retirements might boil down to whether the productivity levels of (presumably) younger newly hired workers can offset the loss of firm-specific knowledge of retiring workers.

In view of this discussion, it is possible to spell out the third hypothesis as follows.

Hypothesis 3: The impact of excess flows is differentiated based on whether they stem from quits, dismissals, or retirements, in unknown directions, depending on which effects prevail.

Another crucial dimension of differentiation is whether excess flows involve high- or lowskilled workers. Central dimensions, according to which the impact of excess flows unfolds, are the importance of firm-specific human capital and the possibility of finding suitable substitute workers. One could reasonably assume that these dimensions play a different importance role for high- and low-skilled workers. Firm-specific human capital seems to play a fundamental part for high-skilled workers (Parsons, 1972). For instance, for a manager, it is vital to deeply know the firm's specificities on production and organization processes; similarly, for a worker that manages delicate matters such as long-standing client or supplier relationships, it is crucial to know the firm's practices and habits (and possibly having experienced them at first hand). Furthermore, finding suitable workers for high-skilled positions seems complicated, as the pool of workers with the required bundle of skills is limited (Cappelli, 2015). These downside aspects could offset the positive ones stemming from the possibility to find better matches given by reallocation dynamics. In the case of low-skilled workers, instead, firm-specific knowledge seems less crucial and the workers' pool is arguably more abundant. Therefore, the potential for an overall positive effect to emerge seems higher for low-skilled workers.

Given these considerations, it is possible to state the fourth hypothesis in the following terms.

Hypothesis 4: The positive (negative) impact of excess flows is reduced (accentuated) for high-skilled workers compared to low-skilled workers. 
The impact of excess flows is also likely to differ across categories of firms. In particular, four dimensions seem relevant: the firm's technology, location in industrial districts, age, and size.

The productivity impact of workers' replacements unravels along the trade-off between the acquisition of new knowledge and the loss of acquired knowledge. The technology of a firm, that is, whether it is a low-tech or a high-tech firm, is likely to substantially affect the relative importance of these two dimensions and, therefore, the resulting impact of excess flows on productivity. The acquisition of new (tacit) knowledge about specific technologies seems to be crucial for high-tech firms. This so-called "learning-by-hiring" effect emerges in a large number of empirical studies for the case of inflows of R\&D workers in high-tech firms (e.g., Herstad et al., 2015; Parrotta and Pozzoli, 2012; Tzabbar et al., 2013). This suggests that in high-tech firms, which generally compete in fast-changing environments, gains from inflows of new knowledge can significantly offset losses from outflows of (perhaps outdated) knowledge. For low-tech firms, instead, it is likely that such benefits from inflows of new knowledge do not substantially compensate for costs associated with replacements (e.g., coordination problems during job vacancy periods).

Location in industrial districts also appears to be a critical dimension of differentiation. The potential for reallocation dynamics to find better employer-employee matches, indeed, strongly depends on the availability of suitable workers for the new, replacement matches. Firms operating in the same district typically share much in terms of production processes and goods produced. Spacial concentration typical of industrial districts creates a specialized labor market pool that firms can easily tap into (Overman and Puga, 2010). Furthermore, workers commonly move across firms in the same district (Serafinelli, 2019). Therefore, replacement workers can represent a unique way to acquire valuable tacit knowledge about the processes and practices of other firms in the same district and to enlarge the firm's networks of connections with them. These factors can significantly overcompensate for costs associated with excess flows. Therefore, one might reasonably expect that the potential for positive effects of reallocation dynamics gets maximum in the presence of industrial districts. Conversely, for firms located outside industrial districts, the potential for positive effects is more limited, and negative forces associated with excess flows might prevail in this case.

Firm age is another dimension of diversification. Excess flows in young firms are typically higher compared to older companies, reflecting the fact that young firms undergo a period of intense experimentation of employer-employee matches (Haltiwanger et al., 2012). That this higher replacement activity of young firms materializes into a positive or negative impact on productivity is mainly an empirical question, which depends on the relative importance role of two opposing mechanisms. On the one hand, it may be that young firms can get maximized benefits from workers' replacements. In the early life of a firm, there might be more room to improve employer-employee matches. Finding good matches at first try might be very unlikely, and more attempts might prove advantageous for the firm. On the other hand, it remains a 
fact that firms in early stages of life have to "practice with the market" and consolidate the understanding of their internal processes, strengths, and weaknesses. Workers' replacements can prevent the achievement of these objectives and consequently hinder the firm's productive performance.

Finally, firm size is likely to moderate the impact of excess flows on productivity due to the different importance role across small and large firms of coordination costs imposed by workers' replacements. In particular, very small firms are likely to enjoy less the benefits associated with excess flows compared to larger firms. In general, they have more difficulties in recruiting new workers, especially those highly-qualified (OECD, 1997). Also, during job vacancy periods, for very small firms, it could be more problematic to reallocate the workforce to perform the extra job previously done by the separated workers (Pauly et al., 2002).

As a result of this discussion, the last set of hypotheses is as follows.

Hypothesis 5: The positive (negative) impact of excess flows is accentuated (reduced) for high-tech firms compared to low-tech firms.

Hypothesis 6: The positive (negative) impact of excess flows is accentuated (reduced) for firms located in industrial districts compared to firms located outside.

Hypothesis 7: Firm age moderates the impact of excess flows in unknown directions, depending on which effects prevail.

Hypothesis 8: The positive (negative) impact of excess flows is reduced (accentuated) for very small firms compared to larger firms.

The rest of the paper is devoted to the empirical test of these eight hypotheses. The next section describes the Veneto case, the object of investigation of the paper.

\section{The Veneto case: labor mobility and Employment protection legislation (EPL)}

Italy was traditionally a country with one of the strictest EPL regimes in the world (Kugler and Pica, 2008). ${ }^{3}$

During the early 1980s, hirings of new workers could only take place through open-ended contracts, except for very particular cases in which firms could use temporary work. Firms could almost exclusively select blue-collar workers from the list of unemployed people rather than through a direct selection mechanism. For firms employing more than 15 workers, individual dismissals were allowed only under a "just cause". Dismissed workers had the right to appeal to

\footnotetext{
${ }^{3} \mathrm{EPL}$ refers to the laws regulating hirings and dismissals, both individual and collective. This section does not discuss rules on collective dismissals since the analysis removes firms that are closing down.
} 
the judge. If the judge ruled the dismissal unfair, the firm was obliged to reinstate the worker and to pay forgone wages (tutela reale, Law No. 300 of 1970, Article 18).

As part of a constant (if slow) trend towards a general liberalization and modernization of the labor market, starting from the mid-1980s, EPL has been somewhat reduced, particularly on the entry side of the market (i.e., hirings). In 1984, the law introduced temporary worktraining contracts (contratti di formazione-lavoro), aimed at encouraging the hiring of young workers by firms. In 1987, temporary contracts started to be also regulated by sectoral collective agreements, and no more only (and strictly) be the law. The early 1990s marked full liberalization of the direct selection mechanism. From that moment to the early 2000s (i.e., throughout the observation window of this paper, 1995-2001), nothing has changed, except for the introduction of the so-called Pacchetto Treu, which has provisioned additional (mild) deregulations on hirings in 1997 (e.g., it legalized the use of temporary work agencies and introduced the use of internship programs). Despite these liberalizations, the use of temporary contracts remained negligible until the early 2000s. Only from the end of 2001 did the standard open-ended contract lose importance in favor of the fixed-term contract. Indeed, in September 2001, Law No. 368 fully liberalized the use of temporary work: the mediation of sectoral collective agreements was no longer needed and temporary work was admitted "for any technical, productive, organizational, or of temporary replacement reason".

In sum, throughout the observation window of this paper, Italy was characterized by a rigid EPL, both on the entry and exit sides of the labor market. Nevertheless, the degree of labor mobility (and excess flows) was in line with that of other countries commonly known for their labor market flexibility, such as the UK (Contini et al., 2008). As part of such a national context, the Veneto labor market was even more mobile (Tattara and Valentini, 2003). The causes of such a stark contrast between law provisions and reality are attributable to the diffusion of illegal practices, the frailty of the control system, and contradictions in the law (Contini et al., 2008). For instance, the "just cause" rule, which would have had the potential to sharply limit workers'

dismissals (and consequently worker flows) has been applied seldom. As Garibaldi et al. (2003) point out, only about $2 \%$ of the individual dismissals went to court and ended up with the reinstatement of the unfairly dismissed worker. In the vast majority of cases, the reinstatement was bypassed either legally, through extrajudicial settlements with severance pay, or illegally, in the form of forced quits. Therefore, firms had ultimately vast degrees of freedom in hiring and firing workers.

\section{Worker flows: definitions and formulas}

Before moving to the description of the empirical model and identification issues, it is useful to make clear the concepts of worker flows used in this paper.

The employment level of firm $i$ at time $t$ is denoted $E_{i t}$. Net worker flows, denoted $N W F_{i t}$, 
refer to a change in the firm's employment. Therefore, $N W F_{i t}=E_{i t}-E_{i t-1}$ is the net variation in the number of workers in the firm between $t$ and $t-1$. Of course, net worker flows can be either positive or negative (or null). When they are positive, the firm experiences net hirings $\left(N H_{i t}\right)$, that is, it is expanding its workforce. When net worker flows are negative, the firm experiences net separations $\left(N S_{i t}\right)$, that is, it is contracting its workforce. Therefore, it is: $N H_{i t}>0$ if $N W F_{i t}>0$ and $N H_{i t}=0$ otherwise; similarly, it is: $N S_{i t}>0$ if $N W F_{i t}<0$ and $N S_{i t}=0$ otherwise.

Total worker flows, denoted $T W F_{i t}$, are defined as the sum between hirings $\left(H_{i t}\right)$ and separations $\left(S_{i t}\right): T W F_{i t}=H_{i t}+S_{i t}$. The net change in employment is the difference between hirings and separations: $N W F_{i t}=H_{i t}-S_{i t}=E_{i t}-E_{i t-1}$. Total worker flows can thus be written as $T W F_{i t}=\left|N W F_{i t}\right|+E W F_{i t}$, where $\left|N W F_{i t}\right|=N H_{i t}$ if $N W F_{i t}>0$ and $\left|N W F_{i t}\right|=N S_{i t}$ if $N W F_{i t}<0$. The total inflows and outflows of workers can, therefore, be split into a net component and an excess component. The net component of total worker flows, $\left|N W F_{i t}\right|$, represents those hirings or separations that serve to increase or decrease the workforce. Whereas, the excess component, $E W F_{i t}$, represents the hirings and separations that do not serve to increase or decrease the workforce but, on the contrary, reflect a churning activity. Said differently, excess flows reflect workers' replacements (Burgess et al., 2000a). ${ }^{4}$

A simple example helps to appreciate the different types of worker flows. Consider a firm with 10 employees at time $t-1$, which hires 2 workers and does not separate from any workers between $t-1$ and $t$. This implies that the number of workers at $t$ is 12 . This firm experiences 2 hirings, 0 separations, total worker flows equal to 2 (2 hirings +0 separations), and excess worker flows equal to 0. In this case, the firm's hirings serve only to expand its workforce. Consider the same firm, with 10 employees at time $t-1$, but now hiring 4 workers and separating from 2 between $t-1$ and $t$. The number of workers at $t$ at is 12 , precisely as in the previous case. Here, however, the firm experiences 4 hirings, 2 separations, total worker flows equal to 6 (4 hirings +2 separations), and excess flows equal to $4(6-2$, where 6 are total worker flows and 2 is the absolute value of net flows). In the first case, the firm increases its workforce by 2 workers and experiences only net inflows. In the second case, the firm increases its workforce by 2 workers, too. Therefore, it experiences net inflows of workers, as in the first case. However, it also experiences worker flows that do not affect the employment level of the firm but only reflect a replacement activity. In particular, it replaces 2 of its workers with 2 new ones.

\footnotetext{
${ }^{4}$ The concept of (and emphasis on) excess flows is relatively recent and was originally proposed in a series of papers by Julia Lane and colleagues (Burgess et al., 2000a,b, 2001; Lane et al., 1996), who, in turn, built on previous studies on net worker flows (e.g., Dunne et al., 1989; Davis and Haltiwanger, 1992; Davis et al., 1996). Note that different names for exactly the same concepts are used in the literature. For instance, net worker flows are sometimes referred to as "job flows" (e.g., in Burgess et al., 2000a) or "net job creation" (e.g., in Davis et al., 1996). Net hirings and net separations are equivalent to "job creation" and "job destruction" in Burgess et al. (2000a). Similarly, excess worker flows are sometimes referred to as "excess worker turnover" (e.g., in Centeno and Novo, 2012) or "worker churning" (e.g., in Burgess et al., 2000a).
} 
Following Davis et al. (1996), I divide all worker flows by the average level of employment, $N_{i t}=\frac{E_{i t}-E_{i t-1}}{2}$. This way, I define, among the other variables, the net hiring rate $\left(N H R_{i t}=\right.$ $\left.\frac{N H_{i t}}{N_{i t}}\right)$, the net separation rate $\left(N S R_{i t}=\frac{N S_{i t}}{N_{i t}}\right)$, and the excess worker flow rate $\left(E W F R_{i t}=\right.$ $\left.\frac{E W F_{i t}}{N_{i t}}\right)$. The net hiring rate gives the number of workers relative to the (average) workforce that are hired by the firm to expand its workforce (i.e., net inflows of workers). On the contrary, the net separation rate gives the number of workers relative to the (average) workforce that separate from the firm to reduce the firm's employment level (i.e., net outflows of workers). Finally, the excess worker flow rate gives the proportion of workers relative to the (average) workforce that separate from and join the firm to reallocate job matches while leaving the firm's employment level unaffected (i.e., replacements of workers). It is crucial to express worker flows in rates rather than levels in the estimating equations because it allows taking into account the size of the firm and the relative weight of worker flows (e.g., replacing one more worker in a 10-employee firm is arguably different from replacing one more worker in a 100-employee firm).

What one defines (and identifies) as net flows and excess flows depends on the level of analysis (and the granularity of the data). If one had the information at the level of tasks, one could define job creation any time a firm creates a new job task and hires a new worker to perform that task. Similarly, one could define job destruction any time a firm eliminates a given job task and separates from the worker who was performing that task. On the contrary, one could define excess flows any time, for a given job task, the firm replaces the worker who was performing that task with another worker, and the job task is neither created nor destroyed. This means that, in such a case, a firm could simultaneously experience job creation and job destruction. For instance, citing an example in Davis et al. (1996), a firm may destroy 10 assembler jobs and create 10 robotics technician jobs. In practice, researchers by no means have information at the level of job task, and consequently have historically defined (and they still do it) net and excess flows at the level of the firm's workforce, as specified in the above formulas (e.g., see Burgess et al., 2000a; Centeno and Novo, 2012; Davis et al., 1996). In other words, worker flows have been implicitly defined based on the notion of jobs as contractual relationships between the workers and the firms, that is, employer-employee matches, rather than bundles of tasks (Burgess et al., 2000a). This means that, with the available data, in the example above, such simultaneous creation and destruction of job tasks would end in the count of excess flows, rather than as net separations and net hirings, respectively. Therefore, from the perspective of job tasks, the result is that net flows are understated and excess flows are overstated. ${ }^{5}$

Two last considerations are worth mentioning. First, for how we (and all the other researchers in the literature on worker flows) have defined worker flows (i.e., at the level of the firm's workforce

\footnotetext{
${ }^{5}$ Defining worker flows at the level of job category (e.g., high- versus low-skilled workers) instead of at the level of the overall firm's workforce is a way to refine the identification of net and excess flows (I do this in additional analyses presented in Subsection 7.2).
} 
and not at the level of job task), a firm can either experience net inflows or net outflows (or none of them if its employment level is constant). This means that the $N H R_{i t}$ and $N S R_{i t}$ cannot be simultaneously different from zero. Second, the excess worker flows are always twice the number of replacements. This is because a replacement converts into two worker flows, one separation and one hiring. For instance, if the $E W F R_{i t}$ is equal to $30 \%$, this means that the firm replaces $15 \%$ of its (average) workforce with new workers.

\section{Empirical model and identification}

To assess the impact of net and excess flows on productivity, this paper uses the following augmented log-linear value-added Cobb-Douglas production function:

$$
y_{i t}=\alpha+\beta_{l} l_{i t}+\beta_{k} k_{i t}+\theta_{1} N H R_{i t}+\theta_{2} N S R_{i t}+\theta_{3} E W F R_{i t}+\gamma F_{i t}+u_{i t} .
$$

$y_{i t}, l_{i t}$, and $k_{i t}$ denote, respectively, the logarithms of value added and labor and capital usage of firm $i$ at time $t$. The term $\alpha$ is the average productivity of the firms. The coefficients $\theta_{1}, \theta_{2}$, and $\theta_{3}$ are the objects of interest of this paper and express the impact of net inflows $\left(N H R_{i t}\right)$, net outflows $\left(N S R_{i t}\right)$, and excess flows $\left(E W F R_{i t}\right)$ on productivity, respectively. The term $F_{i t}$ is a vector of workforce and firm characteristics which may influence productivity, included as controls. Finally, $u_{i t}$ is the error term, that is, the productivity level of firm $i$ at time $t$ that is left unexplained. It is useful to decompose it into two parts. The first component, $\omega_{i t}$, is the firm's productivity level at $t$ that is not observed by the econometrician, but is partly anticipated at $t-1$ and observed at $t$ by the firm. The second component, $\epsilon_{i t}$, is an idiosyncratic error term uncorrelated with regressors.

This empirical setting is commonly called "augmented production function". It hinges on the idea that the firm's production output is influenced not only by standard inputs such as the amounts of labor and capital but also by other production factors, which include the most diverse variables (e.g., workforce composition). It is commonly used in the literature investigating how firm productivity responds to different variables (see, for instance, Parrotta and Pozzoli, 2012, for the case of worker inflows). The coefficients of interest $\left(\theta_{1}, \theta_{2}\right.$, and $\theta_{3}$, in our case) capture the impact of the regressors of interest on the firms' overall productive performance (i.e., actually, their marginal contribution to production output). The discussion in Section 2 presented various mechanisms through which the different worker flows can affect productivity (e.g., those related to firm-specific human capital, tacit knowledge, reallocation dynamics, coordination inefficiencies). All of these mechanisms have the potential to affect both the intrinsic individual productivity of labor and a more firm-wide productivity level (for example, when job vacancies interfere with the effective usage of capital inputs). Disentangling these mechanisms and their impacts on intrinsic productivity of labor versus firm-wide productivity remains outside the scope of this 
paper, which sets itself a more limited, yet important, major intent, that is, to assess the impacts of net and excess worker flows on firms' overall productive performance, what, in fact, coefficients $\theta_{1}, \theta_{2}, \theta_{3}$ capture. $^{6}$

Therefore, it is crucial to estimate consistently $\theta_{1}, \theta_{2}$, and $\theta_{3}$, the parameters measuring the impacts of the different worker flows on productivity. To this end, the empirical analysis needs to address some endogeneity issues.

The first issue is referred to as "simultaneity of inputs". It relates to a well-known problem common to the estimations of production functions, that is, that inputs are endogenous since they respond to the firm's productivity level. For example, a highly productive firm will produce more, using more inputs. Similarly, a productivity improvement (e.g., due to the introduction of a process innovation) will bring an increase in the usage of inputs. This makes inputs correlated with $\omega_{i t}$.

A second issue, specific to this paper, is that worker flows are also endogenous. First, there is an omitted variable bias. Some firm characteristics, unobserved by the econometrician, influence both productivity and worker flows. A case in point is the quality of the firm's management. Firms with good managers generally perform better. At the same time, worker flows are correlated with the quality of managers. Good managers likely bring firms to expansion, resulting in positive net hirings. Similarly, firms with good management might experience lower levels of worker churning: good managers are arguably more able to choose the right workers and retain them. The same may hold for other unobserved firm characteristics, such as the degree of corporate social responsibility or the firm's culture (broadly defined), which can impact on both productivity and worker flows. For instance, a firm that cares about its workers' welfare might be less prone to destruct job positions in a period of crisis, thereby adopting labor hoarding

\footnotetext{
${ }^{6}$ Note that Equation (1) is coherent with modeling the production function of the firm as the union between a set of "standard inputs" (e.g., labor and capital) and a total factor productivity term, typically intended as a firmwide productivity measure, which basically captures the level of production not explained by the standard inputs and which one can model with relevant variables. In practice, one could start modeling the firm's production function as $Y_{i t}=A_{i t} L_{i t}^{\beta_{l}} K_{i t}^{\beta_{k}}$, where $Y_{i t}$ is value added, $L_{i t}$ and $K_{i t}$ are labor and capital, and $A_{i t}$ is the total factor productivity term. One can then model $A_{i t}$ as $A_{i t}=\exp \left\{\alpha+\delta_{1} N H R_{i t}+\delta_{2} N S R_{i t}+\delta_{3} E W F R_{i t}+\gamma F_{i t}+u_{i t}\right\}$. By using these two equations and taking logs, one gets the augmented production function in Equation (1), which is the equation to be estimated in practice. Equation (1) is also coherent (and can be obtained by following some simple algebraic steps) with assuming that, instead of in $A_{i t}$, net inflows, net outflows, and churning workers enter additively in a labor aggregate (together with workers who neither join nor separate from the firm, let us call them $L_{i t}^{\text {stable }}$ ), but with a potentially different intrinsic labor productivity, that is, $L_{i t}=L_{i t}^{\text {stable }}+\gamma_{1} N H_{i t}+\gamma_{2} N S_{i t}+\gamma_{3} E W F_{i t}$ (see Hellerstein et al., 1999, for details). In this case, too, $\gamma_{1}, \gamma_{2}$, $\gamma_{3}$ capture the combination of both firm-wide productivity effects as well as intrinsic differences in individual productivity of the different categories of workers (i.e., net inflows, net outflows, churning workers, and workers who stay). Note that, were one to additionally assume that $A_{i t}$ is a linear function of net and excess flow rates, the separate effects of $\delta_{i}$ (i.e., firm-wide productivity effects) and $\gamma_{i}$ (i.e., intrinsic differences in individual labor productivity) would not be identified in the context of log-linear Cobb-Douglas production functions. More general production functions might, in principle, allow for the identification of the two separate effects. However, in the absence of hard data on individual productivity of labor, as opposed to firm-wide productivity, this task is rather demanding and is not currently pursued in the literature.
} 
strategies. This makes the different worker flows correlated with $\omega_{i t}$. Second, there is a problem of reverse causality. Worker flows affect productivity and, at the same time, they are influenced by productivity. In bad times (i.e., adverse productivity shocks), firms tend to decrease their workforce, while in good times (i.e., positive productivity shocks), they tend to expand their employment level. Moreover, the job-search theory (see, for example, Burdett and Mortensen, 1998) highlights that low-productivity (low-wage) firms are more likely than high-productivity (high-wage) firms to experience quits and, hence, a higher level of excess flows if they want to maintain a constant level of employment. Again, this makes worker flows correlated with $\omega_{i t}$.

In light of these endogeneity issues, ordinary least squares (OLS) estimation of Equation (1) cannot consistently estimate the coefficients of interest (and the input elasticities, $\beta_{l}$ and $\beta_{k}$ ). Fixed effects (FE) estimation cannot properly address the issue either, despite removing the fixed firm-specific productivity level. FE estimation would deliver consistent estimates only if omitted variable bias derived exclusively from unobserved time-invariant variables and inputs and worker flows did not respond to time-varying unobserved (by the econometrician) productivity levels, a rather unrealistic picture. Therefore, a method that can control for a more realistic, articulated framework is needed. The control function approach proposed by Ackerberg et al. (2015) (ACF, hereafter), which refines the methods originally developed by Olley and Pakes (1996) and Levinsohn and Petrin (2003), represents a solution to endogeneity. In a nutshell, ACF propose to use the firm's demand for intermediate inputs to proxy for the unobserved productivity level $\omega_{i t}$. The rationale is that intermediate inputs can capture it. This is because firms can easily adjust their use of intermediate inputs in response to productivity shocks. This paper uses a modified version of the ACF method, developed by Vandenberghe et al. (2013) (ACF-FE,

hereafter), which extends the ACF procedure by explicitly accounting for (and removing) firm fixed effects. This eliminates unobserved fixed firm heterogeneity. It also further increases the ability of the proxy to capture the (fluctuations in the) unobserved productivity level. Appendix A discusses in detail the empirical model and the ACF and ACF-FE methods.

\section{Data}

The data set used in this paper is the result of the match of two separate data sources: Veneto Workers History (VWH) and Analisi Informatizzata delle Aziende Italiane (AIDA).

The VWH data set was constructed by a team led by Giuseppe Tattara at the University of Venice based on administrative data of the Italian Social Security System. It collects labor market histories for the period 1975-2001 of each employee working for at least one day in the private sector (except for agriculture) of Veneto. It is composed of three parts. There is the so-called "worker archive", which collects personal information of the worker (e.g., gender, age, and place of birth). There is the "job archive", which contains information on the job held by the worker in the firm (e.g., hiring date, separation date, if applicable, contract type, and 
qualification). Finally, there is the "firm archive", which provides information about the firm (e.g., the firm's national tax number, used as a firm identifier, location, establishment date, cessation date, if applicable, and industry). These features make VWH a longitudinal matched employer-employee data set. ${ }^{7}$

Unfortunately, VWH does not provide information on balance sheets of firms, which is essential to estimate the production function in Equation (1). This information is retrieved from a different data source, AIDA. It is provided yearly since 1995 by the Bureau van Dijk and contains comprehensive information on balance sheets of all (non-financial and non-agricultural) incorporated private firms in Italy with annual sales above 500,000 Euros. Variables in AIDA include revenues, profits, value added, the book value of tangible, intangible, and financial fixed assets, the expenditure on intermediate inputs, and the firm's national tax number. ${ }^{8}$

The firms' national tax number, used a firm identifier in both VWH and AIDA, is used to match job-year observations in VWH with balance sheet information in AIDA. The match was conceived and conducted by David Card, Francesco Devicienti, and Agata Maida, who describe the matching procedure in Card et al. (2013). The result is a longitudinal matched employeremployee data set (referred to as "VWH-AIDA") for the period 1995-2001, collecting job histories of all employees in all the (non-financial and non-agricultural) incorporated private Veneto firms with revenues higher than 500,000 Euros. ${ }^{9}$

In the empirical analysis, output is measured with value added; labor with the total number of full-time adjusted days worked during the year (VWH-AIDA does not provide information on hours of work); and capital with the book value of tangible fixed assets. Intermediate inputs, used in the ACF and ACF-FE procedures to proxy for the firm's unobserved productivity level, are measured with the expenditure on raw materials, consumables, commodities, services, and other ancillary costs. Output, capital, and intermediate inputs are deflated with the relevant price indexes (see Appendix B.1 for details).

The net hiring rate, net separation rate, and excess worker flow rate are measured based on monthly-level information on the firm's workers (i.e., we know the month in which they joined

\footnotetext{
${ }^{7}$ For a detailed description of VWH, see Tattara and Valentini (2010). There is also an online description of the data at http://www.frdb.org/page/data/scheda/inps-data-veneto-workers-histories-vwh/doc_pk/ 11145. Note, however, that it refers to a restricted version of the data, which covers only the provinces of Treviso and Vicenza.

${ }^{8}$ For a thorough description of AIDA, see https://www.bvdinfo.com/en-gb/our-products/data/national/ aida\#secondaryMenuAnchor0.

${ }^{9}$ The coverage of the VWH-AIDA data set results from the intersection between the coverages of VWH and AIDA, respectively. For instance, while VWH reports data for the period 1975-2001, AIDA starts from 1995. Therefore, the matched data set covers the period 1995-2001. Also, note that other studies have used the VWH data set (alone or in the version matched with AIDA). A list, as complete as possible, of published (or in press) papers using the VWH data set is the following: Bartolucci et al. (2018); Battisti (2017); Card et al. (2013); Chan (2018); Devicienti et al. (2018); Gianelle (2014); Leonardi and Pica (2012); Serafinelli (2019); Tattara and Valentini (2010).
} 
the firm and, if applicable, in which they separated from the firm). This is a unique feature of the VHW-AIDA data set, which allows getting a more precise computation of worker flows that also accounts for work relations starting and ending within a year. Researchers, instead, can typically obtain worker flow measures based on yearly-level information on the stock of workers in the firm, whereby they know the list of workers of each firm at a given point in the year and cannot reconstruct within-year worker flows. Appendix B.2 provides further information on the measurement of worker flows. ${ }^{10}$

I undertake an essential cleaning of the data set, intended to remove unusable observations or observations representing particular cases that could bias the estimates (see Appendix B.3 for details). Since the vast majority of firms (about 67\%) belong to the manufacturing industry, I restrict the attention to them for ensuring a sufficient degree of sample homogeneity. Alternatively, one could preserve the full sample and perform separate analyses by industry. However, as the remaining fraction is split among mining, trade, transportation and telecommunication, services, and construction industries, the sample size would be too small to draw reliable conclusions for these sectors.

The final data set used in the empirical analysis is the firm-level collapsed version of the (cleaned) matched employer-employee data set; it consists of 27,129 firm-year observations for 5,692 firms. ${ }^{11}$ Appendix B.4 provides general descriptive statistics on the data set, which include the distribution of firms by number of panel observations, industry, and size, and several summary statistics about workforce and firm characteristics. Here, instead, the discussion concentrates on worker flows.

Table 1 shows detailed descriptive statistics on the different worker flows, as defined in Section 4. The first panel reports flows in levels, that is, in terms of number of workers (note that the average firm has 59 employees), whereas the second panel expresses flows in rates (i.e., as a proportion of the average employment). On average, firms increase their workforce by $2.9 \%$ in any given year. There are firms experiencing job creation and others experiencing job destruction. The firsts expand their workforce by $6.6 \%$, thus experiencing net inflows of workers, whereas the seconds reduce their employment level by $3.8 \%$, thus experiencing net outflows of workers. This implies that, on average, the absolute value of net flows is $10.4 \%$. Coherently with what emerges from the literature (e.g., Burgess et al., 2000a), also the sampled firms experience total flows much higher than net flows. On average, firms hire a number of workers that is equivalent to as much as $22.9 \%$ of their average employment level and separate from a number of workers equal to $20.0 \%$ of it. This results in total worker flows equal to as much as $42.9 \%$ and excess

\footnotetext{
${ }^{10}$ Thanks to the monthly-level structure of the data, I construct a whole series of workforce controls to be included in the estimating regression (e.g., the shares of females, migrants, part-timers) by weighting workers on a monthly basis. For example, to compute the share of females, a woman who is employed for only two months weights six times less than a woman employed for the whole year.

${ }^{11}$ For brevity, I often say "firms" to indicate "firm-year observations".
} 
flows equal to $32.5 \%$ (i.e., $42.9 \%-10.4 \%$ ), pointing to $32.5 \% / 2=16.3 \%$ of the average workforce replaced with new workers in any given year.

Resorting to the complete VWH data set (i.e., that which covers all but agricultural employees of the Veneto private sector), I classify separated workers into three possible categories, depending on their subsequent presence in the (complete VWH) data. The first category includes workers who make job-to-job transitions. They are separated workers who are observed to start a new job in the same month of the separation or, at most, in the month following the separation. The second category comprises separated workers who are not observed for a longer time (i.e., equal to or greater than two months after the separation) or no more observed in the data (but are not around the retirement age). The third category collects separated workers who are no more observed in the data and are around the retirement age. I argue that job-to-job transitions most likely represent voluntary quits (of workers willing to change jobs). It is likely that a worker who voluntarily quits his/her job (and wants to continue working) has a new job starting in a short time. Similarly, I argue that workers who drop out of the sample around the retirement age most likely retire. Conversely, although workers who exit the sample for a relatively long time or permanently (and are not around the retirement age) can be workers who are dismissed, it is risky to apply this interpretation with too much confidence. Indeed, such an event is also compatible with a withdrawal from the labor market (e.g., to care for the family, for illness), a transfer to another region/country or the public sector, or death.

As shown in the third panel of Table 1, on average, job-to-job transitions represent a substantial fraction of a firm's separations $(40.2 \%)$, in line with the idea that many workers voluntarily quit their jobs. Coherently with the fact that workers retire only once in the lifetime, on average, separations of workers around the retirement age who drop out of the sample collect only $4.4 \%$ of a firm's totality of separations. Finally, separated workers who exit the sample for a relatively long time or permanently (and are not around the retirement age) are, on average, the majority of a firm's separated workers (55.5\%). Even if this category collects a variety of situations, such a large number suggests that dismissals may not be uncommon, coherently with the fact that Italian firms could relatively easily circumvent strict EPL on dismissals.

Finally, the last panel of Table 1 reports relevant worker flow rates separately for low- and high-skilled workers. Notably, it emerges that low-skilled workers, which include blue-collar workers and apprentices, are the most replaced (excess worker flow rate equal to 0.331). Instead, high-skilled workers, which collect white-collar workers and managers, are replaced by as much as $44 \%$ less (excess worker flow rate equal to 0.187 ). 


\section{Results}

\subsection{Main results: worker flows and productivity}

The first column of Table 2 presents the results from the ACF-FE estimation of Equation (1). The vector of controls $\left(F_{i t}\right)$ includes a large variety of worker and firm characteristics. They comprise the shares of females, migrants, part-timers, and temporary workers, and the workforce distribution across age and job category. They also include dummies for firm size, year, and year interacted with industry and province, respectively. Moreover, the ACF-FE estimation removes firm fixed effects, thereby eliminating unobserved fixed firm heterogeneity. The estimates report bootstrapped standard errors, which are robust to heteroskedasticity. ${ }^{12}$

As summarized in Hypothesis 1, whether the overall productivity impacts of net inflows, net outflows, and excess flows are negative or positive is mainly an empirical issue. In each of the three cases (i.e., net hirings, net separations, and excess flows), some mechanisms push toward a positive impact and other toward a negative one, and establishing a priori which will prevail is difficult. From estimations results, it first emerges that the productivity impact of worker flows is differentiated based on the type of worker flow under consideration. Net hirings have a positive and significant impact on productivity, while net separations have a negative and significant effect on it. Positive mechanisms associated with net inflows of workers thus prevail on negative ones. Possible inefficiencies due to initial stages of the learning process are more than offset by gains resulting from inflows of new knowledge. Instead, negative forces associated with net outflows of workers prevail on positive ones. The loss of knowledge, which likely has a sizable firm-specific component, hurts productivity, and the fact that under-performing workers might separate from the firm does not make up for that, on the whole.

When it comes to excess worker flows, the main object of interest of this paper, their estimated impact on productivity is positive and significant. An increase of 10 percentage points in the share of replaced workers (i.e., 20 percentage points in the excess worker flow rate) is estimated to raise productivity by $0.98 \%$, that is, $\left(e^{0.049 * 0.200}-1\right) * 100$. For the average firm, with about 59 workers, such an increase means replacing about 6 workers more. ${ }^{13}$ Excess flows are thus beneficial to firm productivity. The reallocation process of employer-employee matches, which is so pervasive, appears to succeed in its intent of allowing firms to find better matches. Overall, the loss of (firm-specific) knowledge of separated workers, the learning process of replacement workers, and possible coordination inefficiencies due to job vacancy periods are more than offset

\footnotetext{
${ }^{12}$ Appendix $\mathrm{C}$ also shows the OLS, FE, and ACF estimates of Equation (1). Note that, apart from these additional estimates presented in Appendix C, all the results in the paper refer to ACF-FE estimation, have the same set of controls described above, and report bootstrapped standard errors.

${ }^{13}$ The estimated elasticities of labor and capital are 0.865 and 0.094 , respectively, values comparable to those found by the literature on the estimation of value-added production functions (see, for instance, Van Biesebroeck, 2007). Both estimates are significantly different from zero at any conventional level.
} 
by the gains stemming from better employer-employee matched reached. ${ }^{14}$

In Section 2, we have discussed that, while a certain amount of workers' replacements can foster the firm's productive performance, too large amounts might be of detriment. In such case, coordination inefficiencies due to job vacancy periods and losses of large proportions of firmspecific knowledge might overcome benefits from reallocation dynamics. Accordingly, Hypothesis 2 theorized the existence of an inverted U-shape impact, suggesting that there exists a level of excess flows after which they start hindering productivity. This is tested in the second column of Table 2, where a quadratic term in the excess worker flow rate is added to Equation (1). The estimated coefficient associated with the excess worker flow rate is positive, higher than in the basic model (0.088), and significant. The estimated coefficient associated with the quadratic term is negative (-0.057) and significant. This validates the hypothesis that workers' replacements are beneficial up to a certain extent, but they become harmful when they are too many. However, the impact is predicted to be positive up to when the excess worker flow rate is somewhat high (equal to 0.772). This implies that the excess worker flow rate is below the optimum for more than $95 \%$ of the firms. Increases in excess flows are thus beneficial for the vast majority of them, and passing from a zero level of workers' replacements to the optimal level is estimated to boost productivity by as much as $6.99 \%$.

\subsection{Additional results: the role of worker-and firm-level characteristics}

Up to this point, the results suggest that net inflows of workers enhance productivity, while net outflows of workers hurt it. Most importantly, they show that replacing workers is, overall, beneficial to productivity. However, it is likely that the diverse mechanisms through which worker flows impact on productivity play different importance roles depending on several worker- and firm-level aspects, thereby resulting in differentiated impacts. As discussed in Section 2, these aspects include the nature of replacements, the job category of workers moving in and out of the firm, and the firm's technology, location, age, and size. The present subsection aims at understanding how the productivity effects of the different worker flows vary across these dimensions. As the emphasis of the paper is on excess flows, the discussion will focus on them. Moreover, though with varying intensities, the positive impact of net inflows and the negative impact of net outflows is confirmed in all of the different worker and firm categories analyzed. On the contrary, the effect of excess flows is more heterogeneous.

Table 3 reports the results when I allow the impact of excess flows to vary according to the nature of replacements. In practice, I estimate a modified version of Equation (1) that interacts the excess worker flow rate with the relative weights of the different types of separated workers

\footnotetext{
${ }^{14}$ Appendix D presents the results obtained from the estimation of a version of Equation (1) which controls for productivity levels of the firms the newly hired workers come from. If productivity levels of sending and destination firms are correlated, this might confound regression estimates.
} 
(i.e., those who make job-to-job transitions, those who drop out of the sample for longer periods or permanently and are not around the retirement age, and those who drop out of the sample permanently and are around the retirement age). I measure these relative weights as the ratios between each category of separated workers and the total number of separated workers in the firm, as in the third panel of Table 1. For example, the relative weight of job-to-job transitions is the proportion of job-to-job transitions out of the totality of the firm's separations.

As predicted by Hypothesis 3, the impact of excess flows on productivity is differentiated based on whether they stem from quits, dismissals, or retirements. However, as discussed in Section 2, it is arduous to tell a priori whether the directions of these impacts are positive or negative, as numerous contrasting mechanisms are involved. First, results indicate that the impact of replacing separated workers who make job-to-job transitions is positive and significant. When the totality of the firm's separations is attributable to job-to-job transitions (i.e., their relative weight is 1 ), a 10 percentage point increase in the share of replaced workers is estimated to raise productivity by $0.90 \%$. Of course, good workers, that is, those with good matches from the firm's viewpoint, may voluntarily quit. This may happen, for instance, when they "get poached" by higher-productivity firms. However, estimation results support a different story. Those workers who voluntarily quit seem to be typically the bad workers, those with bad matches from the firm's viewpoint. In sum, reallocation dynamics stemming from re-evaluations of matches by workers seem to enhance the firm's productive performance by releasing the firm from sub-optimal matches and allowing it to reach better employer-employee combinations. The meta-analysis by Mc Evoy and Cascio (1987) provides further support to this interpretation. According to their study, poor performers are, in fact, much more likely to voluntarily quit than good performers.

As discussed in Section 2, since retirements are predictable well in advance, the firm likely does not suffer from coordination problems due to job vacancy periods that instead can emerge when workers separate with short notice. Whether the overall effect of excess flows stemming from retirements is positive or negative, therefore, boils down to whether or not the productivity of younger replacement workers can overcompensate for losses of firm-specific knowledge of retiring workers. Results show a sizable positive (0.337) and significant impact when the firm replaces separated workers around the retirement age who are no more observed in the data. This thus supports the idea that higher productivity levels of younger replacement workers more than offset the loss of firm-specific knowledge accumulated by retiring workers. ${ }^{15}$

We discussed that the productivity effect of replacing dismissed workers was not univocal,

\footnotetext{
${ }^{15}$ Between 1995 and 2001, the retirement age decreed by law differed by number of years of work and between men and women. According to the OECD, in that period, the average retirement age in Italy was about 57 years for women and 59 for men. I choose a 55 -year threshold, which seems a reasonable value. I also experimented with different threshold levels, up to 60 years of age. The results remain stable.
} 
too. While firms arguably dismiss (very) under-performing workers, dismissing workers might as well reveal a double-edged sword to the extent that bureaucratic rigidities and other obstacles complicate the dismissal process. The estimated impact of replacing separated workers who drop out of the sample for a relatively long time or permanently (and are not around the retirement age) is positive, but small and not significant, thus suggesting that rigidities associated with dismissals might indeed be relevant. However, while interpretations about quits and retirements should be taken with a grain of salt, it is necessary to take this interpretation about dismissals with even more caution. As mentioned earlier, this category of separated workers includes in all probability workers who are not dismissed, but separate from the firm for other reasons (e.g., for family commitments or transfers to other regions/countries or to the public sector). ${ }^{16}$

Hypothesis 4 predicted that the impact of excess flows also varies according to the categories of workers involved in the replacements, that is, based on whether they are high- or low-skilled workers. In particular, it stated that the positive impact of excess flows is reduced for high-skilled workers compared to low-skilled workers. Table 4 reports the estimation results of a version of Equation 1 in which the three different worker flows (i.e., net hirings, net separations, and excess flows) are computed separately for high- and low-skilled workers. The results indicate that the productivity impact of excess flows is diversified based on the job category in the hypothesized directions. According to the estimates, replacing low-skilled workers has a positive and significant effect, whereas replacing high-skilled workers has a negative effect, but small and not significant. This is coherent with the fact that, on the one hand, firm-specific knowledge accumulated by high-skilled workers plays a more important role compared to low-skilled workers, and, on the other hand, that high-skilled workers are less easily substituted compared to low-skilled workers because the pool of workers with the required bundle of specific skills is more limited.

Section 2 also discussed that the impact of excess flows likely varies across different types of firm characteristics, including the firm's technology, location, age, and size. Table 5 reports the results for this. In practice, I estimated Equation (1) separately (i.e., on split samples) for each firm category.

The first panel of the table reports the results on the distinction based on the firm's technology, that is, high- and low-tech firms. To classify high- and low-tech firms, I follow the classification proposed by the OECD based on R\&D intensities. Among the others, the high-tech industry includes firms operating in the sectors of aircraft and spacecraft, chemicals, automotive, and medical instruments (for a detailed list, see the footnote of Table 5). In the sample, $12.9 \%$

\footnotetext{
${ }^{16}$ To attenuate these concerns, I experimented with a different identification strategy for dismissals, whereby only the workers who reappear in the sample (i.e., are employed in any non-agricultural Veneto firm) within 6 months from separation are included. While this has the disadvantage of leaving out dismissed workers who end up in long periods of unemployment, on the other hand, it has the advantage of excluding workers who are not dismissed but separate from the firm for other reasons such as withdrawals from the labor marker or transfers to other places outside Veneto. The positive, but small and not significant, impact remains.
} 
of the firms are defined as high-tech firms. The results support Hypothesis 5. The positive impact of workers' replacements is accentuated for high-tech firms, coherently with the idea that acquisition of new knowledge from hirings greatly overcompensates for losses of (perhaps outdated) knowledge of separated workers in such firms. A 10 percentage point increase in the share of replaced workers in high-tech firms is estimated to raise productivity by $2.10 \%$. While statistically significant, the impact of the same increase in workers' replacements for low-tech firms is considerably lower $(0.82 \%)$, consistently with the idea that adverse effects linked, for instance, to staffing issues, weight relatively more in low-tech companies.

The second panel of Table 5 reports the results from the estimation of Equation (1) separately for firms located in industrial districts and firms located outside. Hypothesis 6 theorized that the benefits associated with excess flows are maximized for firms located in industrial districts. Industrial districts are characterized by specialized labor market pools which guarantee easy replacements of separated workers. At the same time, inflows of (tacit) knowledge on processes and routines of other firms operating in the same district might be extremely valuable to destination firms, and might greatly overcompensate for losses of firm-specific knowledge of separated workers and staffing issues during job vacancy periods. I identify industrial districts from the list given by the Osservatorio Nazionale dei Distretti Industriali (the Italian monitoring center of industrial districts). Among the others, they include the eyewear district in Belluno; the district of ceramic, porcelain, and artistic glass in Vicenza; the district of artistic glass in Murano (Venice); the district of wood and furniture covering the whole region; the footwear district in Verona; and the district of mechatronic and innovative mechanical technologies across Veneto. ${ }^{17}$ In the sample, as much as $50.6 \%$ of the firms belong to industrial districts, consistently with their significant diffusion in Veneto. The results strongly support expectations. The impact for firms located in industrial districts is positive, larger than the overall effect (0.078), and significant. For these firms, a 10 percentage point increase in the share of replaced workers is estimated to raise productivity by about $1.57 \%$. Conversely, the impact on firms that do not belong to industrial districts is small and not significant. Therefore, it emerges that highly-specialized labor market pools and high interconnections among origin and destination firms greatly enhance the potential for reallocation dynamics to foster productivity.

Hypothesis 7 established that firm age moderates the impact of excess flows on productivity, in unknown directions. On the one hand, an intense reallocation activity might be beneficial to set better employer-employee matches in the early life of a firm. On the other hand, when a firm is in its infancy, workers' replacements might hinder the consolidation of the firm's (understanding of its) routines and processes. Whether the first mechanism prevails or not on the latter is mainly an empirical matter. The third panel of Table 5 shows the estimated impact of excess

\footnotetext{
${ }^{17}$ For a detailed list, see http://www.osservatoriodistretti.org/category/regione/Veneto.
} 
flows separately for young and old firms. I define young firms as those whose average age in the observation window is lower or equal to 5 years. Accordingly, I define old firms as those above 5 years of (average) age. About $9.8 \%$ of the firms in the sample are defined as young. According to the estimates, the impact of workers' replacements on young firms is negative (-0.053), even if not statistically significant. This points to a predominance of harmful mechanisms behind excess flows for the case of young firms, or, at least, to lower importance of positive forces. Old firms, instead, experience a positive impact of excess flows, slightly higher than the average impact, thus suggesting that firm age is indeed a relevant dimension of differentiation. ${ }^{18}$

Finally, the last panel of Table 5 reports the results for the separate estimation of Equation (1) by firm size. I define very small firms as those whose average (over the years) number of employees is less than 15. About $12.3 \%$ of the firms in the sample are very small firms. The results support Hypothesis 8, that is, that the benefits from excess flows reduce for very small firms. The estimated impact for them is, in fact, very small in magnitude (0.001) and largely not significant. On the contrary, the estimated impact for other firms is positive and significant, slightly higher than the average effect. This suggests that higher difficulties in recruiting replacement workers and higher coordination problems associated with job vacancy periods for very small firms significantly hinder beneficial mechanisms of excess flows, which instead clearly emerge for bigger firms. ${ }^{19}$ Interestingly, very small firms are estimated to experience no benefits from excess flows even if the EPL concerning dismissals was remarkably less strict for them. On the contrary, bigger firms, subjected to a more rigid EPL, are estimated to gain from reallocation dynamics significantly. This casts light on the fact that EPL, rigidly designed as it may be, is often circumvented by firms, which generally need positive excess flows to perform better.

\section{Conclusions}

This paper investigated the productivity impact of workers' movements in and out of the firm, distinguishing between three structurally distinct worker flows, namely, net inflows, net outflows, and excess flows. The analysis used a matched employer-employee data set, which allowed reconstructing detailed worker flow dynamics of manufacturing Veneto firms over the period 1995-2001. Endogeneity issues stemming from unobserved heterogeneity and simultaneity were addressed by using state-of-the-art semi-parametric methods, based on the use of intermediate inputs to proxy for the firm's unobserved productivity level.

\footnotetext{
${ }^{18}$ Since it is not obvious what a young firm is, I performed the estimation using different threshold levels, namely, below 4, 6, and 7 (average) years of age. The results are similar to those for the 5 -year threshold. Note that further decreasing the threshold drastically reduces the size of the group of young firms. For instance, only $2.8 \%$ of the firms have an (average) age below 3 years.

${ }^{19}$ As for the case of age, since it is not obvious what a very small firm is, I performed the estimation using alternately different threshold levels, namely below 12,13 and 14 (average number of) employees. The results are similar to those for the 15-employee threshold.
} 
While net inflows and net outflows derive from the firm's evaluation of its optimal employment level and represent necessary events to attain it, excess flows are, in this sense, not necessary. They are hirings and separations that do not increase nor decrease the workforce but entail the replacement of workers with new ones. These excess flows are the outcome of a process of continuous re-evaluation, by firms and by workers, of the quality of the matches. While this paper has assessed the productivity impact of all of these flows, it has predominantly focused on excess worker flows, the most prominent (and compelling) feature of worker flows.

Veneto firms in the 1990 s are an excellent object of observation to study the productivity impacts of excess flows. In that period, Veneto was characterized by nearly full employment and was one of the wealthiest countries in Italy, on a par with other most industrialized European countries, such as Germany. This means that excess flows arose from pure reallocation dynamics aimed at searching for more productive matches, rather than from pathological job destruction in (certain sectors of) the economy. Furthermore, despite strict EPL, Italy (and Veneto especially) were characterized by a high degree of labor mobility, similar to that of other countries commonly known for their labor market flexibility, such as the UK. Such a dynamic context allows grasping the effects of reallocation dynamics fully. Moreover, the diffusion of industrial districts typical of Veneto allows studying how the productivity impact of reallocation dynamics unfolds in such a peculiar industrial setting, which, to various degrees, also characterizes many industrialized countries (e.g., the Ruhr district in Germany). Furthermore, the fact that VWH-AIDA data covers a large part of the population of employees and firms allows studying reallocation dynamics based on a self-contained labor market.

Net hirings are estimated to have a positive impact on productivity, consistently with the idea that inflows of new knowledge benefit the firm. Conversely, net separations are estimated to be of detriment to productivity, pointing to the fact that outflows of (firm-specific) knowledge damage the firm. Most importantly, excess flows are estimated to enhance productivity. Reallocation dynamics at the basis of excess flows, thus, succeed in the intent of allowing firms to find more productive employer-employee matches. Notably, a positive effect emerges even if there are solid bases for harmful mechanisms to materialize, for instance, the fact that workers' replacements entail the loss of (firm-specific) human capital of separated workers and adjustment phases during learning processes of the new workers, as well as possible coordination and logistic inefficiencies during job vacancy periods.

Our results have broad managerial and policy implications.

Firms should perceive excess flows as an opportunity for productivity enhancement. They should take into account that workers' replacements give the possibility to find more productive matches, which, in a world of imperfect information, often prove sub-optimal. Not only, the results indicate that excess flows that are not fully controllable by the firm (i.e., stemming from quits), are those that in practice increase productivity. This suggests that those who quit are 
generally badly-matched workers. Firms should thus consider quits as a good thing: a worker that judges the match a bad match and leaves the firm is typically right. Moreover, managers should consider that excess flows allow the firm to acquire new knowledge and enlarge its networks of connections, which can substantially overcompensate for losses of human and social capital of separated workers. These considerations are especially important for managers who head high-tech firms and firms located in industrial districts, which, in fact, are found to benefit from excess flows substantially. Inflows of new knowledge about specific technologies and practices of sending firms, likely operating in the same market/district, are assets precious to such firms and substantially overcompensate for adverse mechanisms associated with workers' replacements.

However, managers should pay attention that excess flows do not become dysfunctional for the firm. This happens when workers' replacements involve a substantial share of the firm's employment (i.e., above around $40 \%$ of the workforce). At such high levels, harmful effects associated with workers' replacements become preponderant. Losses of firm-specific human capital of separated workers, long learning processes of newly hired workers, and coordination and logistic problems during job vacancy periods are the underlying mechanisms. In these (borderline) cases, managers should invest in more effective recruitment practices and do their best to create a good working environment able to retain employees. Similarly, they should be more watchful when excess flows involve high-skilled workers and when they head young or very small firms, as the positive effects are found to disappear in those cases. Successfully replacing high-skilled workers is hard: firm-specific human capital plays a fundamental role and finding suitable workers with the required bundles of skills is difficult. Young firms need to acquire some experience with the market and deepen their understanding of internal processes before reallocation dynamics exhibit their positive effects. Very small firms instead suffer from more limited access to the labor market pool and high coordination inefficiencies emerging during job vacancy periods. However, it is crucial to stress that even if excess flows of such workers and in such firms do not boost productivity, estimates suggest that they are never of significant detriment to firms.

Policy makers in Italy have historically designed laws to limit worker mobility: in the 1990s, and to a smaller degree nowadays, Italy was one of the countries with the strictest EPL. The results of this paper strongly call for a reconsideration of this approach, which to varying degrees of intensity is common to many of the European countries. First, besides increasing productivity levels of single firms, on an aggregate basis, a certain extent of excess flows also allows the entire economy to be more productive. Moreover, even though single firms reward knowledge inflows and not outflows, excess flows allow, on an aggregate basis, knowledge to spread out in the whole economy, which is a crucial determinant for aggregate productivity growth. Second, reallocation dynamics may also benefit workers. Reaching better matches can also favor them, in the form of higher wages, better career prospects, and greater gratification from work. This applies, in particular, to policy makers that intervene in economies characterized by a high density of 
high-tech firms and by a division of the territory into industrial districts. Policy makers could also consider launching programs to help managers who head firms with dysfunctional rates of workers' replacements to implement more effective recruiting schemes and create better working environments. 


\section{Table 1: Sample summary statistics: worker flows}

\begin{tabular}{|c|c|c|}
\hline Variable & Mean & Std. dev. \\
\hline Net worker flows $\left(N W F_{i t}\right)$ & 1.429 & 13.372 \\
\hline Absolute value of net worker flows $\left(\left|N W F_{i t}\right|\right)$ & 4.808 & 12.559 \\
\hline $\bar{O} f^{-}$which: & & \\
\hline Net hirings $\left(N H_{i t}\right)$ & 3.119 & 10.690 \\
\hline Net separations $\left(N S_{i t}\right)$ & 1.690 & 7.348 \\
\hline$\overline{\text { Hirings }}\left(\bar{H}_{i t}\right)^{-}-\cdots-\cdots$ & 11.624 & 23.854 \\
\hline 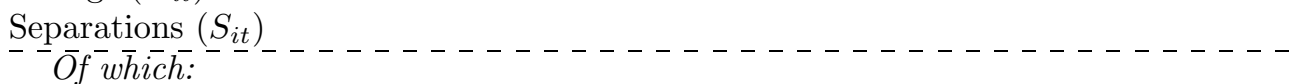 & 10.194 & 19.942 \\
\hline Workers who make job-to-job transitions & 3.973 & 7.346 \\
\hline $\begin{array}{l}\text { Workers who drop out of the sample for a relatively long time or permanently (and } \\
\text { are not around the retirement age) }\end{array}$ & 5.760 & 12.653 \\
\hline Workers who drop out of the sample around the retirement age & 0.461 & 1.979 \\
\hline$\overline{\text { Total }}$ ' worker $\overline{\text { flows }}{ }^{-1}\left(\bar{T} \bar{W} \bar{F}_{i t}^{-}\right) \ldots \ldots$ & 21.818 & 41.888 \\
\hline Excess worker flows $\left(E W F_{i t}\right)$ & 17.009 & 33.763 \\
\hline Net worker flow rate $\left(N W F R_{i t}\right)$ & 0.029 & 0.166 \\
\hline $\begin{array}{l}\text { Absolute value of net worker flow rate }\left(\left|N W F R_{i t}\right|\right) \\
-{ }_{-} \bar{O} f^{-} \text {which } \bar{c} \text { : }\end{array}$ & 0.104 & 0.132 \\
\hline Net hiring rate $\left(N H R_{i t}\right)$ & 0.066 & 0.106 \\
\hline Net separation rate $\left(N S R_{i t}\right)$ & 0.038 & 0.106 \\
\hline$\overline{\text { Hiring rate }}\left(\bar{H} \bar{R}_{i t}\right)$ & 0.229 & 0.165 \\
\hline 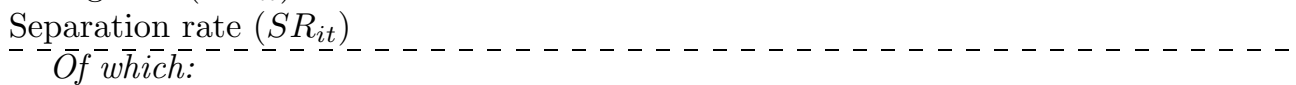 & 0.200 & 0.149 \\
\hline Rate of workers who make job-to-job transitions & 0.082 & 0.081 \\
\hline $\begin{array}{l}\text { Rate of workers who drop out of the sample for a relatively long time or permanently } \\
\text { (and are not around the retirement age) }\end{array}$ & 0.112 & 0.107 \\
\hline Rate of workers who drop out of the sample around the retirement age & 0.007 & 0.017 \\
\hline$\left.\overline{\text { Total }} \overline{\text { worker flow rate }}-\overline{(} \bar{T} \bar{W} \bar{F} \bar{R}_{i t}^{-}\right)^{-}$ & 0.429 & 0.267 \\
\hline Excess worker flow rate $\left(E W F R_{i t}\right)$ & 0.325 & 0.222 \\
\hline \multicolumn{3}{|l|}{ Different types of separations* } \\
\hline Proportion of separated workers who make job-to-job transitions & 0.402 & 0.269 \\
\hline $\begin{array}{l}\text { Proportion of separated workers who drop out of the sample for a relatively long time } \\
\text { or permanently (and are not around the retirement age) }\end{array}$ & 0.555 & 0.269 \\
\hline $\begin{array}{l}\text { Proportion of separated workers who drop out of the sample around the retirement } \\
\text { age }\end{array}$ & 0.044 & 0.113 \\
\hline \multicolumn{3}{|l|}{ Low-skilled versus high-skilled workers ${ }^{* *}$} \\
\hline Excess worker flow rate of low-skilled workers & 0.331 & 0.300 \\
\hline Net hiring rate of low-skilled workers & 0.076 & 0.136 \\
\hline Net separation rate of low-skilled workers & 0.044 & 0.122 \\
\hline Excess worker flow rate of high-skilled workers & 0.187 & 0.326 \\
\hline Net hiring rate of high-skilled workers & 0.083 & 0.181 \\
\hline Net separation rate of high-skilled workers & 0.052 & 0.163 \\
\hline
\end{tabular}

Firm-year observations: 27,129

Firms: 5,692

Source: VWH-AIDA data set

*I remove firms experiencing no separations, amounting to 1,062, since I cannot calculate the proportions of separated workers in each state for them.

**I first compute worker flows at the qualification level, that is, for blue-collar workers, apprentices, whitecollar workers, and managers. Then, I sum up worker flows of blue-collar workers and apprentices (white-collar workers and managers) to get worker flows of low-skilled workers (high-skilled workers). Finally, I obtain rates by dividing worker flows of low- and high-skilled workers with the relevant employment levels. 
Table 2: Main results: the impact of worker flows on firm productivity

\begin{tabular}{|c|c|c|c|c|}
\hline \multicolumn{5}{|c|}{ Dependent variable: $y_{i t}$} \\
\hline$l_{i t}$ & $0.865^{* * *}$ & $(0.054)$ & $0.860^{* * *}$ & $(0.051)$ \\
\hline$k_{i t}$ & $0.094^{* * *}$ & $(0.010)$ & $0.096^{* * *}$ & $(0.010)$ \\
\hline Excess worker flow rate $\left(E W F R_{i t}\right)$ & $0.049^{* * *}$ & $(0.009)$ & $0.088^{* * *}$ & $(0.023)$ \\
\hline Excess worker flow rate $\left(E W F R_{i t}\right)$ - squared & & & $-0.057^{* *}$ & $(0.025)$ \\
\hline Net hiring rate $\left(N H R_{i t}\right)$ & $0.117^{* *}$ & $(0.056)$ & $0.095^{* *}$ & $(0.045)$ \\
\hline Net separation rate $\left(N S R_{i t}\right)$ & $-0.185^{* * *}$ & $(0.053)$ & $-0.196^{* * *}$ & $(0.036)$ \\
\hline Share of females & -0.048 & $(0.054)$ & -0.050 & $(0.053)$ \\
\hline Share of migrants & 0.036 & $(0.063)$ & 0.035 & $(0.063)$ \\
\hline Share of workers under 25 & -0.081 & $(0.059)$ & -0.081 & $(0.059)$ \\
\hline Share of workers aged between 25 and 34 & 0.009 & $(0.052)$ & 0.008 & $(0.052)$ \\
\hline Share of workers aged between 35 and 49 & 0.041 & $(0.048)$ & 0.041 & $(0.048)$ \\
\hline Share of part-timers & 0.053 & $(0.072)$ & 0.052 & $(0.072)$ \\
\hline Share of temporary workers & -0.024 & $(0.039)$ & -0.024 & $(0.039)$ \\
\hline Share of blue-collar workers & 0.128 & $(0.090)$ & 0.128 & $(0.090)$ \\
\hline Share of white-collar workers & 0.009 & $(0.090)$ & 0.009 & $(0.090)$ \\
\hline Share of apprentices & -0.028 & $(0.103)$ & -0.024 & $(0.039)$ \\
\hline Firm fixed effects & yes & & yes & \\
\hline Size dummies & yes & & yes & \\
\hline Year dummies & yes & & yes & \\
\hline Year*industry dummies & yes & & yes & \\
\hline Year*province dummies & yes & & yes & \\
\hline
\end{tabular}

Firm-year observations: 27,129

Firms: 5,692

Source: VWH-AIDA data set

Estimation method: ACF-FE. Bootstrapped standard errors in parentheses; ***, **, and * denote, respectively, the 1\%, 5\%, and 10\% significance level. The reference group for the shares of blue-collar workers, white-collar workers, and apprentices is the share of managers; for the age distribution, it is the share of workers over 50. Size dummies consist of 4 dummies (one for each size category as defined in Table B.2); industry dummies, interacted with year dummies, consist of 114 dummies (one for each 3-digit Ateco 1991 sector); province dummies, interacted with year dummies, consist of 7 dummies (one for each Veneto province). 


\section{Table 3: Additional results: the impact of different types of excess flows}

\begin{tabular}{l|lc}
\hline \hline $\begin{array}{l}\text { Excess worker flow rate }\left(E W F R_{i t}\right) * \text { proportion of separated workers who make job- } \\
\text { to-job transitions }\end{array}$ & $0.045^{* * *}$ & $(0.013)$ \\
$\begin{array}{l}\text { Excess worker flow rate }\left(E W F R_{i t}\right) * \text { proportion of separated workers who drop out } \\
\text { of the sample for a relatively long time or permanently (and are not around the } \\
\text { retirement age) }\end{array}$ & 0.019 & $(0.025)$ \\
$\begin{array}{l}\text { Excess worker flow rate }\left(E W F R_{i t}\right) * \text { proportion of separated workers who drop out } \\
\text { of the sample around the retirement age }\end{array}$ & $0.337^{* * *}$ & $(0.130)$ \\
Net hiring rate $\left(N H R_{i t}\right)$ & $0.142^{* * *}$ & $(0.032)$ \\
Net separation rate $\left(N S R_{i t}\right)$ & $-0.166^{* * *}$ & $(0.017)$ \\
\hline
\end{tabular}

Firm-year observations: 25,616

Firms: 5,649

Source: VWH-AIDA data set

Estimation method: ACF-FE. I include the main effects of the proportions of different types of separated workers among the set of endogenous variables since they are likely to be endogenous. I remove firms experiencing no separations, amounting to 1,062, since I cannot calculate the proportions of separated workers in each state for them. These estimates include the same set of controls in Table 2. For the rest, see the footnote of Table 2.

Table 4: Additional results: the impact of worker flows for low-skilled and highskilled workers

\begin{tabular}{|c|c|c|}
\hline Excess worker flow rate $\left(E W F R_{i t}\right)$ of low-skilled workers & $0.052^{* * *}$ & $(0.019)$ \\
\hline Excess worker flow rate $\left(E W F R_{i t}\right)$ of high-skilled workers & -0.015 & $(0.011)$ \\
\hline Net hiring rate $\left(N H R_{i t}\right)$ of low-skilled workers & $0.064^{* * *}$ & $(0.023)$ \\
\hline Net hiring rate $\left(N H R_{i t}\right)$ of high-skilled workers & $0.128^{* * *}$ & $(0.028)$ \\
\hline Net separation rate $\left(N S R_{i t}\right)$ of low-skilled workers & $-0.100^{* * *}$ & $(0.031)$ \\
\hline Net separation rate $\left(N S R_{i t}\right)$ of high-skilled workers & $-0.240^{* *}$ & $(0.100)$ \\
\hline \multicolumn{3}{|c|}{$\begin{array}{r}\text { Firm-year observations: } 26,696 \\
\text { Firms: } 5,590\end{array}$} \\
\hline
\end{tabular}

Source: VWH-AIDA data set

Estimation method: ACF-FE. I remove firms that do not employ any low-or high-skilled workers, amounting to 397, since I cannot compute worker flow rates separately for low- or high-skilled workers for them. These estimates include the same set of controls of Table 2. For the rest, see the footnote of Table 2. For definitions of high-and low-skilled workers and computation of relative worker flows, see the footnote of Table 1. 
Table 5: Additional results: the impact of worker flows for different types of firms

\begin{tabular}{|c|c|c|}
\hline \multicolumn{3}{|c|}{ High-tech firms versus low-tech firms } \\
\hline High-tech firms & \multirow{10}{*}{$\begin{array}{l}0.104^{* * *} \\
0.572^{* * *} \\
-0.655^{* * *} \\
3,498 \\
\\
0.041^{* *} \\
0.105^{* * *} \\
-0.168^{* *} \\
23,631\end{array}$} & \multirow{5}{*}{$\begin{array}{l}(0.023) \\
(0.194) \\
(0.075)\end{array}$} \\
\hline Excess worker flow rate $\left(E W F R_{i t}\right)$ & & \\
\hline Net hiring rate $\left(N H R_{i t}\right)$ & & \\
\hline Net separation rate $\left(N S R_{i t}\right)$ & & \\
\hline Firm-year observations & & \\
\hline \multicolumn{2}{|l|}{ Low-tech firms } & \\
\hline \multicolumn{2}{|l|}{ Excess worker flow rate $\left(E W F R_{i t}\right)$} & \\
\hline Net hiring rate $\left(N H R_{i t}\right)$ & & $(0.030)$ \\
\hline Net separation rate $\left(N S R_{i t}\right)$ & & $(0.077)$ \\
\hline Firm-year observations & & \\
\hline \multicolumn{3}{|c|}{ Firms located in an industrial district versus firms located outside } \\
\hline \multicolumn{3}{|l|}{ Firms located in an industrial district } \\
\hline Excess worker flow rate $\left(E W F R_{i t}\right)$ & \multirow{5}{*}{$\begin{array}{l}0.078^{* * *} \\
0.300^{* * *} \\
-0.271^{* * *} \\
13,719\end{array}$} & $(0.022)$ \\
\hline Net hiring rate $\left(N H R_{i t}\right)$ & & $(0.070)$ \\
\hline Net separation rate $\left(N S R_{i t}\right)$ & & $(0.063)$ \\
\hline \multicolumn{2}{|l|}{ Firm-year observations } & \\
\hline Firms not located in an industrial district & & \\
\hline Excess worker flow rate $\left(E W F R_{i t}\right)$ & \multirow{4}{*}{$\begin{array}{l}0.018 \\
0.030^{* *} \\
-0.189^{* * *} \\
13,410\end{array}$} & $(0.018)$ \\
\hline Net hiring rate $\left(N H R_{i t}\right)$ & & $(0.014)$ \\
\hline Net separation rate $\left(N S R_{i t}\right)$ & & $(0.019)$ \\
\hline Firm-year observations & & \\
\hline \multicolumn{3}{|c|}{ Old firms versus young firms } \\
\hline Old firms & \multirow{5}{*}{$\begin{array}{l}0.055^{* * *} \\
0.087^{* *} \\
-0.237^{* * *} \\
24,478\end{array}$} & \multirow{5}{*}{$\begin{array}{l}(0.012) \\
(0.034) \\
(0.057)\end{array}$} \\
\hline Excess worker flow rate $\left(E W F R_{i t}\right)$ & & \\
\hline Net hiring rate $\left(N H R_{i t}\right)$ & & \\
\hline Net separation rate $\left(N S R_{i t}\right)$ & & \\
\hline \multirow{2}{*}{\multicolumn{3}{|c|}{$\begin{array}{l}\text { Firm-year observations } \\
\text { Young firms }\end{array}$}} \\
\hline & & \\
\hline Excess worker flow rate $\left(E W F R_{i t}\right)$ & \multirow{4}{*}{$\begin{array}{l}-0.053 \\
0.502^{* *} \\
-0.119^{*} \\
2,651\end{array}$} & \multirow{4}{*}{$\begin{array}{l}(0.046) \\
(0.239) \\
(0.065)\end{array}$} \\
\hline Net hiring rate $\left(N H R_{i t}\right)$ & & \\
\hline Net separation rate $\left(N S R_{i t}\right)$ & & \\
\hline Firm-year observations & & \\
\hline \multicolumn{3}{|c|}{ Bigger firms versus very small firms } \\
\hline Bigger firms & \multirow{6}{*}{$\begin{array}{l}0.054^{* * *} \\
0.168^{* * *} \\
-0.234^{* * *} \\
23,784\end{array}$} & \multirow{5}{*}{$\begin{array}{l}(0.017) \\
(0.054) \\
(0.038)\end{array}$} \\
\hline Excess worker flow rate $\left(E W F R_{i t}\right)$ & & \\
\hline Net hiring rate $\left(N H R_{i t}\right)$ & & \\
\hline Net separation rate $\left(N S R_{i t}\right)$ & & \\
\hline Firm-year observations & & \\
\hline \multicolumn{2}{|l|}{ Very small firms } & \\
\hline Excess worker flow rate $\left(E W F R_{i t}\right)$ & 0.001 & $(0.044)$ \\
\hline Net hiring rate $\left(N H R_{i t}\right)$ & $0.094^{* * *}$ & $(0.030)$ \\
\hline Net separation rate $\left(N S R_{i t}\right)$ & $-0.139^{* * *}$ & $(0.049)$ \\
\hline Firm-year observations & 3,345 & \\
\hline
\end{tabular}

Source: VWH-AIDA data set

Estimation method: ACF-FE. High-tech sectors include: aircraft and spacecraft; chemicals; office, accounting, and computing machinery; radio, TV, and communications equipment; medical, precision, and optical instruments; electrical machinery and apparatus, n.e.c.; motor vehicles, trailers, and semi-trailers; railroad equipment and transport equipment, n.e.c.; machinery and equipment, n.e.c. I pinpoint firms belonging to an industrial district by looking at those firms that belong to the 2- or 3-digit Ateco 1991 sector and province which identify an industrial district. These estimates include the same set of controls of Table 2. For the rest, see the footnote of Table 2. 


\section{References}

Abelson, M. A., Baysinger, B. D., 1984. Optimal and Dysfunctional Turnover: Toward an Organizational Level Model. Academy of Management Review 9 (2), 331-341.

Ackerberg, D. A., Caves, K., Frazer, G., 2015. Identification Properties of Recent Production Function Estimators. Econometrica 83 (6), 2411-2451.

Bartolucci, C., Devicienti, F., Monzón, I., 2018. Identifying Sorting in Practice. American Economic Journal: Applied Economics 10 (4), 408-438.

Battisti, M., 2017. High Wage Workers and High Wage Peers. Labour Economics 46, 47-63.

Becker, G. S., 1964. Human Capital: A Theoretical and Empirical Analysis, with Special Reference to Education. National Bureau of Economic Research, New York, NY.

Bingley, P., Westgaard-Nielsen, N., 2004. Personnel Policy and Profit. Journal of Business Research $57,557-563$.

Broschak, J. P., 2004. Managers' Mobility and Market Interface: The Effect of Managers' Career Mobility on the Dissolution of Market Ties. Administrative Science Quarterly 49 (4), 608-640.

Burdett, K., Mortensen, D. T., 1998. Wage Differentials, Employer Size, and Unemployment. International Economic Review 39 (2), 257-273.

Burgess, S., Lane, J. I., Stevens, D. W., 2000a. Job Flows, Worker Flows, and Churning. The Journal of Labor Economics 18 (3), 473-502.

Burgess, S., Lane, J. I., Stevens, D. W., 2000b. The Reallocation of Labour and the Lifecycle of Firms. Oxford Bulletin of Economics and Statistics 61 (s1), 885-907.

Burgess, S., Lane, J. I., Stevens, D. W., 2001. Churning Dynamics: An Analysis of Hires and Separations at the Employer Level. Labour Economics 8 (1), 1-14.

Cappelli, P. H., 2015. Skill Gaps, Skill Shortages, and Skill Mismatches: Evidence and Arguments for the United States. Industrial \& Labor Relations Review 68 (2), 251-290.

Card, D., Devicienti, F., Maida, A., 2013. Rent-Sharing, Holdup, and Wages: Evidence from Matched Panel Data. The Review of Economic Studies 81 (1), 84-111.

Centeno, M., Novo, A. A., 2012. Excess Worker Turnover and Fixed-Term Contracts: Causal Evidence in a Two-Tier System. Labour Economics 19 (3), 320-328.

Chan, J., 2018. Does Import Competition Worsen the Gender Gap? Evidence from Matched Employer-Employee Data. Economics Letters 165, 13-16. 
Contini, B., Leonbruni, R., Pacelli, L., Villosio, C., 2008. The Structure of Wages: an International Comparison. The University of Chicago Press, Chicago, IL, Ch. Wage Mobility and Dynamics in Italy in the 1990s, pp. 373-400.

Davis, S. J., Haltiwanger, J. C., 1992. Gross Job Creation, Gross Job Destruction, and Employment Reallocation. Quarterly Journal of Economics 107 (3), 819-863.

Davis, S. J., Haltiwanger, J. C., 1999. Gross Job Flows. In: Ashenfelter, O., Card, D. (Eds.), Handbook of Labor Economics. Vol. 3. Elsevier, Amsterdam, NL, pp. 2711-2805.

Davis, S. J., Haltiwanger, J. C., Schuh, S., 1996. Job Creation and Destruction. MIT Press, Cambridge, MA.

Devicienti, F., Grinza, E., Vannoni, D., 2018. The Impact of Part-Time Work on Firm Productivity: Evidence from Italy. Industrial and Corporate Change 27 (2), 321-347.

Dosi, G., Grazzi, M., 2010. On the Nature of Technologies: Knowledge, Procedures, Artifacts and Production Inputs. Cambridge Journal of Economics 34 (1), 173-184.

Dunne, T., Roberts, M. J., Samuelson, L., 1989. Plant Turnover and Gross Employment Flows in the U.S. Manufacturing Sector. Journal of Labor Economics 7 (1), 48-71.

Garibaldi, P., Pacelli, L., Borgarello, A., 2003. Employment Protection Legislation and the Size of the Firm. Giornale degli Economisti e Annali di Economia 63 (1), 33-68.

Garnero, A., Kampelmann, S., Rycx, F., 2014. Part-Time Work, Wages, and Productivity: Evidence from Belgian Matched Panel Data. Industrial \& Labor Relations Review 67 (3), 926-954.

Gianelle, C., 2014. Labor Market Intermediaries Make the World Smaller. Journal of Evolutionary Economics 24 (5), 951-981.

Glebbeek, A. C., Bax, E., 2004. Is High Employee Turnover Really Harmful? An Empirical Test Using Company Records. Academy of Management Journal 47 (2), 277-286.

Grant, R. M., 1996. Toward a Knowledge-Based Theory of the Firm. Strategic Management Journal 17 (s2), 109-122.

Haltiwanger, J., Hyatt, H., McEntarfer, E., Sousa, L., 2012. Business Dynamics Statistics Briefing: Job Creation, Worker Churning, and Wages at Young Businesses. Tech. rep., Kauffman Foundation Statistical Brief. 
Hellerstein, J. K., Neumark, D., Troske, K. R., 1999. Wages, Productivity, and Worker Characteristics: Evidence from Plant-Level ProductionFunctions and Wage Equations. Journal of Labor Economics 17 (3), 409-446.

Herstad, S. J., Sandven, T., Ebersberger, B., 2015. Recruitment, Knowledge Integration and Modes of Innovation. Research Policy 44 (1), 138-153.

Hom, P. W., Griffeth, R. W., 1995. Employee Turnover. Southwestern Publishing, Cincinnati, $\mathrm{OH}$.

Huselid, M. A., 1995. The Impact of Human Resource Management Practices on Turnover, Productivity, and Corporate Financial Performance. Academy of Management Journal 38 (3), 635-672.

Jovanovic, B., 1979. Job Matching and the Theory of Turnover. Journal of Political Economy 87 (5), 972-990.

Kugler, A., Pica, G., 2008. Effects of Employment Protection on Worker and Job Flows: Evidence from the 1990 Italian Reform. Labour Economics 15 (1), 78-95.

Lane, J. I., Isaac, A. G., Stevens, D. W., 1996. Firm Heterogeneity and Worker Turnover. Review of Industrial Organization 11 (3), 275-291.

Lazear, E. P., 2009. Firm-Specific Human Capital: A Skill-Weights Approach. Journal of Political Economy 117 (5), 914-940.

Lazear, E. P., McCue, K., 2017. Hires and Separations in Equilibrium, NBER Working Paper No. 23059.

Leonardi, M., Pica, G., 2012. Who Pays for it? The Heterogeneous Wage Effects of Employment Protection Legislation. The Economic Journal 123 (573), 1236-1278.

Levinsohn, J., Petrin, A., 2003. Estimating Production Functions Using Inputs to Control for Unobservables. The Review of Economic Studies 70 (2), 317-341.

Mawdsley, J. K., Somaya, D., 2016. Employee Mobility and Organizational Outcomes: An Integrative Conceptual Framework and Research Agenda. Journal of Management 42 (1), 85-113.

Mc Evoy, G. M., Cascio, W. F., 1987. Do Good or Poor Performers Leave? A Meta-Analysis of the Relationship between Performance and Turnover. Academy of Management Journal 30 (4), $744-762$.

Nonaka, I., 1994. A Dynamic Theory of Organizational Knowledge Creation. Organization Science 5 (1), 14-37. 
OECD, 1997. Small Businesses, Job Creation and Growth: Facts, Obstacles and Best Practices. Tech. rep., Organisation for Economic Co-operation and Development.

Olley, S. G., Pakes, A., 1996. The Dynamics of Productivity in the Telecommunications Equipment Industry. Econometrica 64 (6), 1263-1297.

Overman, H. G., Puga, D., 2010. Labor Pooling as a Source of Agglomeration: An Empirical Investigation. In: Glaeser, E. L. (Ed.), Agglomeration Economics. The University of Chicago Press, Chicago, IL, pp. 133-150.

Parrotta, P., Pozzoli, D., 2012. The Effect of Learning by Hiring on Productivity. The RAND Journal of Economics 43 (1), 167-185.

Parsons, D. O., 1972. Specific Human Capital: An Application to Quit Rates and Layoff Rates. Journal of Political Economy 80 (6), 1120-1143.

Pauly, M. V., Nicholson, S., Xu, J., Polsky, D., Danzon, P. M., 2002. A General Model of the Impact of Absenteeism on Employers and Employees. Health Economics 11 (3), 221-231.

Polanyi, M., 1958. Personal Knowledge: Towards a Post-Critical Philosophy. The University of Chicago Press, Chicago, IL.

Polanyi, M., 1966. The Tacit Dimension. Routledge \& Kegan Paul, London, UK.

Serafinelli, M., 2019. "Good" Firms, Worker Flows and Productivity. Journal of Labor Economics, Forthcoming.

Sforzi, F., 1989. Small Firms and Industrial Districts in Italy. Routledge, London, UK, Ch. The Geography of Industrial Districts in Italy, pp. 153-173.

Shaw, J. D., 2011. Turnover Rates and Organizational Performance: Review, Critique, and Research Agenda. Organizational Psychology Review 1 (3), 187-213.

Shaw, J. D., Duffy, M. K., Johnson, J. L., Lockhart, D. E., 2005. Turnover, Social Capital Losses, and Performance. Academy of Management Journal 48 (4), 594-606.

Siebert, S. W., Zubanov, N., 2009. Searching for The Optimal Level of Employee Turnover: A Study of a Large U.K. Retail Organization. Academy of Management Journal 52 (2), 294-313.

Somaya, D., Williamson, I. O., Lorinkova, N., 2008. Gone but Not Lost: The Different Performance Impacts of Employee Mobility between Cooperators versus Competitors. Academy of Management Journal 51 (5), 936-953. 
Stoyanov, A., Zubanov, N., 2012. Productivity Spillovers Across Firms through Worker Mobility. American Economic Journal: Applied Economics 4 (2), 168-198.

Stoyanov, A., Zubanov, N., 2014. The Distribution of the Gains from Spillovers through Worker Mobility between Workers and Firms. European Economic Review 70, 17-35.

Tattara, G., Valentini, M., 2003. Un Mercato del Lavoro molto Mobile? Sì, ma con molti se e molti ma. Economia e Società Regionale (1), 24-54.

Tattara, G., Valentini, M., 2010. Turnover and Excess Worker Reallocation. The Veneto Labour Market between 1982 and 1996. Labour 24 (4), 474-500.

Ton, Z., Huckman, R. S., 2008. Managing the Impact of Employee Turnover on Performance: The Role of Process Conformance. Organization Science 19 (1), 55-68.

Tzabbar, D., Aharonson, B. S., Amburgey, T. L., 2013. When Does Tapping External Sources of Knowledge Result in Knowledge Integration? Research Policy 42 (2), 481-494.

Van Biesebroeck, J., 2007. Robustness of Productivity Estimates. The Journal of Industrial Economics 55 (3), 529-569.

Vandenberghe, V., 2012. Are Firms Willing to Employ a Greying and Feminizing Workforce? Labour Economics 22, 30-46.

Vandenberghe, V., Rigo, M., Waltenberg, F., 2013. Ageing and Employability. Evidence from Belgian Firm-Level Data. Journal of Productivity Analysis 40 (1), 111-136. 


\section{Appendices}

\section{A. The empirical model and the ACF and ACF-FE estimation methods}

As discussed in Section 5, the estimating equation is:

$$
y_{i t}=\alpha+\beta_{l} l_{i t}+\beta_{k} k_{i t}+\theta_{1} N H R_{i t}+\theta_{2} N S R_{i t}+\theta_{3} E W F R_{i t}+\gamma F_{i t}+u_{i t} .
$$

I assume that the unobserved productivity level, $\omega_{i t}$, is regulated by a first-order Markov process; that its realization at $t$ is observed by the firm at $t$ (i.e., contemporaneously); and that it is at least partially anticipated by the firm. Therefore, it is possible to write:

$$
E\left[\omega_{i t} \mid I_{i t-1}\right]=g\left(\omega_{i t-1}\right) \quad \text { and } \quad \omega_{i t}=g\left(\omega_{i t-1}\right)+\xi_{i t},
$$

where: $I_{i t-1}$ is the information set of firm $i$ at time $t-1 ; g(\cdot)$ is a general function and $g\left(\omega_{i t-1}\right)$ represents the component of $\omega_{i t}$ that is predictable by the firm at $t-1$; and $\xi_{i t}$ is the innovation in $\omega_{i t}$, observed by the firm at $t$ and, by construction, unpredictable by the firm at $t-1$ (i.e., $\left.E\left[\xi_{i t} \mid I_{i t-1}\right]=0\right)$. Basically, firms observe $\omega_{i t}$ at $t$ and form expectations on $\omega_{i t}$ at $t-1$ by using $g(\cdot)$.

I also assume that capital is a non-perfectly variable input. This means that the firm decides upon the amount of capital to use in the production process at $t$ one period earlier, at $t-1$. This assumption is consistent with the presence of capital adjustment costs accounting for the fact that new capital takes time to be ordered, delivered, installed, and put into operation. Conversely, I assume that labor is a perfectly variable input. This means that the firm decides upon the amount of labor to use at $t$ in the same period, at $t$. Coherently with the assumption that labor is a perfectly variable input, I assume that also net hirings, net separations, and excess flows at $t$ are determined at $t$. This is consistent with the following situation: (i) at $t$, the firm decides upon the level of $l_{i t}$ (and, therefore, upon $N H_{i t}$ and $N S_{i t}$ ), that is, it decides whether to keep the employment level at the same level of $t-1$, to increase it, through net inflows, or to decrease it, through net outflows; (ii) at $t$, the firm also decides whether to replace any workers at $t$; (iii) workers make and communicate at $t$ their decision to quit at $t$; (iv) on the basis of (i), (ii), and (iii), the firm decides at $t$ whether to dismiss and/or hire any workers at $t$.

I further assume that intermediate inputs are perfectly variable inputs; that the firm's demand for intermediate inputs, $m_{i t}$, is a function of labor, capital, the three components of worker flows (i.e., net hirings, net separations, and excess flows - all expressed in rates), and the firm's unobserved productivity level; and that this function is strictly increasing in $\omega_{i t}$ :

$$
m_{i t}=f\left(l_{i t}, k_{i t}, N H R_{i t}, N S R_{i t}, E W F R_{i t}, \stackrel{+}{\omega}_{i t}\right)
$$


Intuitively, this amounts to require that the higher the unobserved productivity level, the larger the demand for intermediate inputs. If this (strict) monotonicity assumption on $f$ holds, $f$ can be inverted out to deliver an expression of $\omega_{i t}$ as a function of $l_{i t}, k_{i t}, N H R_{i t}, N S R_{i t}, E W F R_{i t}$, and $m_{i t}$, which are observable:

$$
\omega_{i t}=f^{-1}\left(l_{i t}, k_{i t}, N H R_{i t}, N S R_{i t}, E W F R_{i t}, m_{i t}\right)
$$

This expression for $\omega_{i t}$ can be substituted into Equation (A.1) to bring:

$$
\begin{aligned}
y_{i t}=\alpha+\beta_{l} l_{i t}+ & \beta_{k} k_{i t}+\theta_{1} N H R_{i t}+\theta_{2} N S R_{i t}+E W F R_{i t}+\gamma F_{i t}+ \\
& +f^{-1}\left(l_{i t}, k_{i t}, N H R_{i t}, N S R_{i t}, E W F R_{i t}, m_{i t}\right)+\epsilon_{i t} .
\end{aligned}
$$

At this point, ACF propose a two-step strategy to recover estimates of $\beta_{l}, \beta_{k}, \theta_{1}, \theta_{2}$, and $\theta_{3}$ (and $\gamma$ ). In the first step, $y_{i t}$ is nonparametrically regressed against a function in $l_{i t}, k_{i t}, N H R_{i t}$, $N S R_{i t}, E W F R_{i t}, m_{i t}$, and $F_{i t}$, referred to as $\Phi\left(l_{i t}, k_{i t}, N H R_{i t}, N S R_{i t}, E W F R_{i t}, m_{i t}, F_{i t}\right)$. A.1 From this regression, it is possible to identify the composite term:

$$
\widehat{\Phi}_{i t}^{*}=\alpha+\beta_{l} l_{i t}+\beta_{k} k_{i t}+\theta_{1} N H R_{i t} \widehat{+} \theta_{2} N S R_{i t}+\theta_{3} E W F R_{i t}+\omega_{i t} .
$$

Note that these are just the predicted values of $y_{i t}$ from the regression minus the estimated $\hat{\gamma} F_{i t}$. Given guesses of $\beta_{l}, \beta_{k}, \theta_{1}, \theta_{2}$, and $\theta_{3}$, respectively denoted $\beta_{l}^{*}, \beta_{k}^{*}, \theta_{1}^{*}, \theta_{2}^{*}$, and $\theta_{3}^{*}$, it is then possible to recover implied $\omega_{i t}, \hat{\omega}_{i t}\left(\beta_{l}^{*}, \beta_{k}^{*}, \theta_{1}^{*}, \theta_{2}^{*}, \theta_{3}^{*}\right)^{\text {A.2 }}$, as:

$$
\hat{\omega}_{i t}\left(\beta_{l}^{*}, \beta_{k}^{*}, \theta_{1}^{*}, \theta_{2}^{*}, \theta_{3}^{*}\right)=\widehat{\Phi}_{i t}^{*}-\beta_{l}^{*} l_{i t}-\beta_{k}^{*} k_{i t}-\theta_{1}^{*} N H R_{i t}-\theta_{2}^{*} N S R_{i t}-\theta_{3}^{*} E W F R_{i t} .
$$

Recalling the assumption that $\omega_{i t}$ follows a first-order Markov process (i.e., $\left.\omega_{i t}=g\left(\omega_{i t-1}\right)+\xi_{i t}\right)$ and given $\hat{\omega}_{i t}\left(\beta_{l}^{*}, \beta_{k}^{*}, \theta_{1}^{*}, \theta_{2}^{*}, \theta_{3}^{*}\right)$, it is possible to compute the implied innovations, $\hat{\xi}_{i t}\left(\beta_{l}^{*}, \beta_{k}^{*}, \theta_{1}^{*}, \theta_{2}^{*}, \theta_{3}^{*}\right)$, as the residuals from a nonparametric regression of $\hat{\omega}_{i t}\left(\beta_{l}^{*}, \beta_{k}^{*}, \theta_{1}^{*}, \theta_{2}^{*}, \theta_{3}^{*}\right)$ on $\hat{\omega}_{i t-1}\left(\beta_{l}^{*}, \beta_{k}^{*}, \theta_{1}^{*}, \theta_{2}^{*}, \theta_{3}^{*}\right)$. ${ }^{\text {A.3 }}$ In the second step, the sample analogues of the moment conditions imposed by the model ${ }^{\mathrm{A} .4}$ are

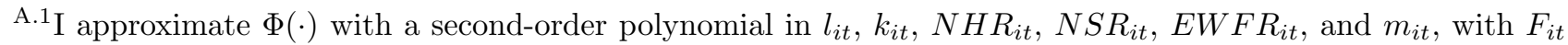
added linearly. I also tried with higher-order (third- and fourth-order) polynomials. The results remain stable.

A.2 They also include the constant term $\alpha$, which ends up not mattering.

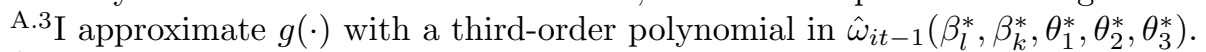

A.4 Stemming from the assumptions that capital is a non-perfectly variable input, labor is a perfectly variable input, and net inflows, net outflows, and excess flows at $t$ are determined at $t$, they are: $E\left[\xi_{i t} k_{i t}\right]=0, E\left[\xi_{i t} l_{i t-1}\right]=$ $0, E\left[\xi_{i t} N H R_{i t-1}\right]=0, E\left[\xi_{i t} N S R_{i t-1}\right]=0$, and $E\left[\xi_{i t} E W F R_{i t-1}\right]=0$.
} 
evaluated:

$$
\begin{aligned}
& \frac{1}{N} \frac{1}{T} \sum_{i} \sum_{t} \hat{\xi}_{i t}\left(\beta_{l}^{*}, \beta_{k}^{*}, \theta_{1}^{*}, \theta_{2}^{*}, \theta_{3}^{*}\right) k_{i t}=0 \\
& \frac{1}{N} \frac{1}{T} \sum_{i} \sum_{t} \hat{\xi}_{i t}\left(\beta_{l}^{*}, \beta_{k}^{*}, \theta_{1}^{*}, \theta_{2}^{*}, \theta_{3}^{*}\right) l_{i t-1}=0 \\
& \frac{1}{N} \frac{1}{T} \sum_{i} \sum_{t} \hat{\xi}_{i t}\left(\beta_{l}^{*}, \beta_{k}^{*}, \theta_{1}^{*}, \theta_{2}^{*}, \theta_{3}^{*}\right) N H R_{i t-1}=0 \\
& \frac{1}{N} \frac{1}{T} \sum_{i} \sum_{t} \hat{\xi}_{i t}\left(\beta_{l}^{*}, \beta_{k}^{*}, \theta_{1}^{*}, \theta_{2}^{*}, \theta_{3}^{*}\right) N S R_{i t-1}=0 \\
& \frac{1}{N} \frac{1}{T} \sum_{i} \sum_{t} \hat{\xi}_{i t}\left(\beta_{l}^{*}, \beta_{k}^{*}, \theta_{1}^{*}, \theta_{2}^{*}, \theta_{3}^{*}\right) E W F R_{i t-1}=0
\end{aligned}
$$

The search over $\beta_{l}^{*}, \beta_{k}^{*}, \theta_{1}^{*}, \theta_{2}^{*}$, and $\theta_{3}^{*}$ continues until $\hat{\beta}_{l}, \hat{\beta}_{k}, \hat{\theta_{1}}, \hat{\theta_{2}}$, and $\hat{\theta}_{3}$ are found that satisfy Equation (A.3). These are the ACF estimates of $\beta_{l}, \beta_{k}, \theta_{1}, \theta_{2}$, and $\theta_{3}$.

The ACF-FE method only modifies the first stage of the ACF procedure. In this framework, the unobserved productivity term explicitly accounts for firm fixed effects, so that the estimating equation can be written as:

$$
y_{i t}=\alpha+\beta_{l} l_{i t}+\beta_{k} k_{i t}+\theta_{1} N H R_{i t}+\theta_{2} N S R_{i t}+\theta_{3} E W F R_{i t}+\gamma F_{i t}+\eta_{i}+\omega_{i t}^{*}+\epsilon_{i t},
$$

where the firm's unobserved productivity level $\omega_{i t}$ is now split into $\eta_{i}$, the time-invariant component, and $\omega_{i t}^{*}$, the time-varying component.

I assume that the demand for intermediate inputs depends on the amounts of labor and capital inputs, net inflows, net outflows, and excess flows, and $\omega_{i t}^{*}$, thus excluding that it also depends on $\eta_{i}$. This assumption is coherent with the idea that the demand for intermediate inputs, which are assumed to be perfectly variable, depends only on time-varying components. Hence, Equation (A.2) here becomes:

$$
\begin{aligned}
y_{i t}=\alpha+\beta_{l} l_{i t}+\beta_{k} k_{i t}+ & \theta_{1} N H R_{i t}+\theta_{2} N S R_{i t}+\theta_{3} E W F R_{i t}+\gamma F_{i t}+\eta_{i}+ \\
& +f^{-1}\left(l_{i t}, k_{i t}, N H R_{i t}, N S R_{i t}, E W F R_{i t}, m_{i t}\right)+\epsilon_{i t} .
\end{aligned}
$$

As before, setting:

$$
\begin{aligned}
& \Phi\left(l_{i t}, k_{i t}, N H R_{i t}, N S R_{i t}, E W F R_{i t}, m_{i t}, F_{i t}\right) \equiv \\
& \equiv \alpha+\beta_{l} l_{i t}+\beta_{k} k_{i t}+ \theta_{1} N H R_{i t}+\theta_{2} N S R_{i t}+\theta_{3} E W F R_{i t}+\gamma F_{i t}+ \\
&+f^{-1}\left(l_{i t}, k_{i t}, N H R_{i t}, N S R_{i t}, E W F R_{i t}, m_{i t}\right)
\end{aligned}
$$


it is possible to write Equation (A.4) as follows:

$$
y_{i t}=\Phi\left(l_{i t}, k_{i t}, N H R_{i t}, N S R_{i t}, E W F R_{i t}, m_{i t}, F_{i t}\right)+\eta_{i}+\epsilon_{i t} .
$$

The ACF-FE procedure now performs nonparametric FE estimation to remove $\eta_{i}$. At this point, it is possible to obtain an estimate of $\Phi(\cdot)$ that explicitly removes firm fixed effects, so that it is possible to proceed to the second stage of the estimation procedure (unchanged with respect to the ACF method) from:

$$
\widehat{\Phi}_{i t}^{*}=\alpha+\beta_{l} l_{i t}+\beta_{k} k_{i t}+\theta_{1} N H R_{i t} \widehat{+\theta}_{2} N S R_{i t}+\theta_{3} E W F R_{i t}+\omega_{i t}^{*}
$$

\section{B. Details on data and measurement issues}

\section{B.1. Deflation of output and inputs}

I deflate value added with the value-added deflator provided by Istat. This deflator is at the 3-digit level of the Ateco 1991 classification of economic activities. I deflate the book value of tangible fixed assets with the deflator for capital goods used in the manufacturing industry provided by Istat. I deflate the expenditure on intermediate inputs with the deflator for intermediate inputs used in the manufacturing industry provided by Istat.

\section{B.2. Measurement of worker flows}

Researchers can often observe stocks of employment only at a given point in the year (e.g., on the 31st of December), for short indicated as $t$. The firm's hirings in a given year are then identified by looking at workers employed in the firm at $t$ but not at $t-1$. Similarly, separations are identified by looking at workers employed in the firm at $t-1$ but not at $t$. In this case, any employment relationship that begins after $t-1$ and terminates before $t$ does not enter the count of hirings and separations, even if it represents one hiring and one separation for the firm in that year. Hence, the worker flows computed with yearly-level information are undercounted. Since VWH-AIDA allows observing a monthly history of each job held by a worker in a given firm, it is possible to compute worker flows more precisely (i.e., in a way that also accounts for employment relations starting and ending within a year). In particular, I use two variables present in the original version of the VWH data set. One indicates the month and year of the hiring, whereas the other indicates the month and year of the separation, if applicable, for each job. Essentially, if the hiring date is equal to or after January of the given year, it is a hiring. If the separation date is prior or equal to December of the given year, it is a separation.

\section{B.3. Data cleaning}

While VWH refers to establishment-level data (i.e., reports information for all the Veneto establishments of a firm), AIDA refers to firm-level data (i.e., possibly including non-Veneto establishments). To alleviate this issue, the analysis excludes firms for which the number of employees 
reported by VWH is less than a half compared to that reported by AIDA. The analysis only considers firms established (still alive) at least one calendar year before (after) I observe them in order to exclude worker flows derived from firm entry (exit). ${ }^{\text {B.1 }}$ As a further precaution, the analysis focuses on firms classified as "active", thus excluding firms that are closing down. Moreover, I remove firms with less than 10 employees. The rationale for this is twofold. First, it serves to clean the data from systematic actions taken to improve the appearance of the company's balance sheet (e.g., showing tangible fixed assets at their acquisition cost irrespective of their market value). These practices are common among very small firms, where accounting procedures are generally less strict (e.g., there is usually no statutory audit). Second, it allows computing meaningfully worker flow rates. The analysis also removes relatively few firms with implausibly high excess flow rates. It applies a threshold of 1 , meaning that the firm replaces at least $50 \%$ of its (average) workforce in a given year. Lastly, the analysis has to exclude firms with non-positive or missing book values of value added, tangible fixed assets, and expenditure on intermediate inputs; moreover, to apply the ACF and ACF-FE methods, the sample has to be restricted to firms observed for at least two consecutive years.

\section{B.4. General descriptive statistics}

Table B.1 shows the distribution of firms by number of consecutive panel observations. I observe about $54 \%$ of the firms for at least 5 consecutive years, while I observe $27.2 \%$ of them throughout the sample period.

Table B.2 reports the distribution of firms by industry and size. Consistently with the specializations typical of Veneto manufacturing firms, firms in the sectors of ferrous and machinery products, furniture, food and beverage, textile, clothing, and leather are the most numerous in the sample. Moreover, consistently with the diffusion of small- and medium-sized enterprises in Veneto, firms employing less than 50 workers are the most common in the sample $(70 \%$ of the firms).

Table B.3 presents summary statistics of several workforce and firm characteristics. On average, firms employ about 59 workers and earn about 11 million Euros per year in revenues. The average firm is about 16 years old and gets 14 Euros of net profit out of 1,000 Euros of sales. In the typical firm, $29.5 \%$ of the workers are females, $6.2 \%$ are migrants, $15.8 \%$ are under 25 , $75 \%$ are in the central age category (between 25 and 49 years old), and $9.1 \%$ of them are over 50. A few of them are employed on a part-time basis $(4.2 \%)$ or are temporary workers $(3.9 \%)$. In the average firm, the vast majority of employees are blue- $(69.7 \%)$ or white-collar workers $(23.7 \%)$. Some of them are in a period of apprenticeship (4.4\%), and a few fill a managerial position (1.3\%). On average, workers tend to stay in the same firm for about 6.5 years.

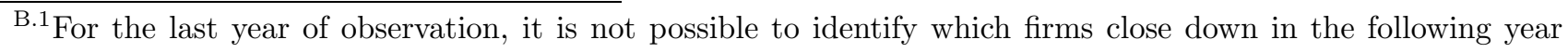
and, consequently, to eliminate them from the sample.
} 


\section{Table B.1: Distribution of firms by number of consecutive panel observations}

\begin{tabular}{l|l|l}
\hline \hline Number of consecutive panel observations & Firms & Observations \\
\hline 2 & 1,063 & 2,126 \\
3 & 824 & 2,472 \\
4 & 638 & 2,552 \\
5 & 574 & 2,870 \\
6 & 1,042 & 6,252 \\
7 & 1,551 & 10,857 \\
\hline Total & 5,692 & 27,129 \\
\hline \hline
\end{tabular}

Source: VWH-AIDA data set

Table B.2: Distribution of firms by industry and size

\begin{tabular}{|c|c|c|}
\hline Industry* & Observations & Percentage \\
\hline Food and beverage & 1,233 & 4.5 \\
\hline Textile & 1,257 & 4.6 \\
\hline Clothing & 1,422 & 5.2 \\
\hline Leather and leather goods & 2,002 & 7.4 \\
\hline Wood and wood products (excluding furniture) & 871 & 3.2 \\
\hline Paper and paper products & 615 & 2.3 \\
\hline Printing and publishing & 680 & 2.5 \\
\hline Coke and petroleum products & 71 & 0.3 \\
\hline Chemical products & 827 & 3.1 \\
\hline Rubber and plastics & 1,423 & 5.3 \\
\hline Non-ferrous production & 1,833 & 6.8 \\
\hline Ferrous production & 624 & 2.3 \\
\hline Ferrous products (excluding machinery) & 4,212 & 15.5 \\
\hline Machinery products & 3,829 & 14.1 \\
\hline Office machinery and computers & 55 & 0.2 \\
\hline Electrical machinery & 1,226 & 4.5 \\
\hline Radio, TV, and TLC equipment & 298 & 1.1 \\
\hline Medical equipment and measurement instruments & 826 & 3.0 \\
\hline Motor vehicles & 293 & 1.1 \\
\hline Other transportation equipment & 202 & 0.7 \\
\hline Furniture and other manufacturing industries & 3,330 & 12.3 \\
\hline Total & 27,129 & 100 \\
\hline Size & Observations & Percentage \\
\hline$[10-20)$ Employees** & 7,095 & 26.2 \\
\hline$[20-50)$ Employees** & 11,755 & 43.3 \\
\hline$[50-250)$ Employees** & 7,566 & 27.9 \\
\hline$\geq 250$ Employees** & 713 & 2.6 \\
\hline Total & 27,129 & 100 \\
\hline
\end{tabular}

Source: VWH-AIDA data set

*Industry is defined according to the 2-digit Ateco 1991 classification of economic activities.

**Monthly weighted. 
Table B.3: Sample summary statistics: general information

\begin{tabular}{|c|c|c|c|}
\hline Variable & Notes & Mean & Std. dev. \\
\hline Employees & Monthly weighted & 58.791 & 139.138 \\
\hline Revenues & 1,000 Euros (2000's prices) & $10,709.700$ & $27,653.470$ \\
\hline Profit margin & Net profit over revenues & 0.014 & 0.053 \\
\hline Firm age & Years & 15.578 & 7.853 \\
\hline Share of females & Monthly weighted & 0.295 & 0.237 \\
\hline Share of migrants & Monthly weighted & 0.062 & 0.085 \\
\hline Share of workers under 25 & Monthly weighted & 0.158 & 0.112 \\
\hline Share of workers aged between 25 and 34 & Monthly weighted & 0.384 & 0.129 \\
\hline Share of workers aged between 35 and 49 & Monthly weighted & 0.366 & 0.141 \\
\hline Share of workers over 50 & Monthly weighted & 0.091 & 0.077 \\
\hline Average workers' age & Monthly weighted & 34.652 & 3.772 \\
\hline Share of part-timers & Monthly weighted & 0.042 & 0.057 \\
\hline Share of temporary workers & Monthly weighted & 0.039 & 0.056 \\
\hline Share of blue-collar workers & Monthly weighted & 0.697 & 0.166 \\
\hline Share of white-collar workers & Monthly weighted & 0.237 & 0.155 \\
\hline Share of apprentices & Monthly weighted & 0.044 & 0.065 \\
\hline Share of managers & Monthly weighted & 0.013 & 0.029 \\
\hline Average workers' tenure & Years & 6.518 & 3.176 \\
\hline Value added & 1,000 Euros (2000's prices) & $2,885.354$ & $8,530.419$ \\
\hline $\log$ Value added & 1,000 Euros (2000's prices) & 7.324 & 0.961 \\
\hline Days worked & FTE adjusted & $17,439.500$ & $40,886.290$ \\
\hline $\log$ Days worked & FTE adjusted & 9.284 & 0.834 \\
\hline Book value of tangible fixed assets & 1,000 Euros (2000's prices) & $1,703.781$ & $4,984.799$ \\
\hline log Book value of tangible fixed assets & 1,000 Euros (2000's prices) & 6.412 & 1.411 \\
\hline Expenditure on intermediate inputs & 1,000 Euros (2000's prices) & $5,930.346$ & $16,597.030$ \\
\hline log Expenditure on intermediate inputs & 1,000 Euros (2000's prices) & 7.767 & 1.290 \\
\hline \multicolumn{4}{|c|}{ Firm-year observations: 27,129} \\
\hline
\end{tabular}

Source: VWH-AIDA data set

\section{Worker flows and productivity: the OLS, FE, and ACF estimates}

Table C.1 shows the OLS, FE, and ACF estimates of Equation (1). Net hirings and net separations are estimated to have, respectively, a significant positive and negative impact on productivity across all the three estimation methods, though with varying intensities. The OLS, FE, and $\mathrm{ACF}$ estimates of the impact of excess flows are instead heterogeneous.

According to the OLS estimates (first column of Table C.1), the impact of excess flows is negative (-0.031) and significant. When controlling for firm fixed effects (FE estimation, second column of Table C.1), the estimated impact becomes positive (0.015) and significant. This is in line with the idea that firms with good management (a feature that can be considered almost fixed during my relatively short panel) systematically attain higher productivity levels and, at the same time, experience lower levels of excess flows, possibly because good managers are abler in choosing the right matches. It is also in line with the idea that firms characterized by generally high productivity levels experience fewer quits and, consequently, fewer excess flows. However, while the FE estimator removes firm fixed effects, it does not account for time-varying unobserved firm heterogeneity and reverse causality stemming from fluctuations in the firm's unobserved productivity level. Contrary to the FE estimation, the ACF method is designed to deal with all the endogeneity problems due to unobserved firm heterogeneity and reverse causality, but it 
does not explicitly remove firm fixed effects. According to the ACF estimates (third column of Table C.1), the impact is negative, much smaller than that predicted by OLS (-0.009), and not significant. This indicates that explicitly accounting for firm fixed effects is crucial to help the ACF method to perform better.

Table C.1: The impact of worker flows on firm productivity: OLS, FE, and ACF estimates

\begin{tabular}{|c|c|c|c|c|c|c|}
\hline Variable & OLS & & FE & & ACF & \\
\hline$l_{i t}$ & $0.910^{* * *}$ & $(0.007)$ & $0.832^{* * *}$ & $(0.020)$ & $0.872^{* * *}$ & $(0.015)$ \\
\hline$k_{i t}$ & $0.128^{* * *}$ & $(0.002)$ & $0.066^{* * *}$ & $(0.007)$ & $0.136^{* * *}$ & $(0.004)$ \\
\hline Excess worker flow rate $\left(E W F R_{i t}\right)$ & $-0.031^{* * *}$ & $(0.010)$ & $0.015^{* * *}$ & $(0.005)$ & -0.009 & $(0.018)$ \\
\hline Net hiring rate $\left(N H R_{i t}\right)$ & $0.110^{* * *}$ & $(0.029)$ & $0.115^{* *}$ & $(0.050)$ & $0.113^{* * *}$ & $(0.035)$ \\
\hline Net separation rate $\left(N S R_{i t}\right)$ & $-0.337^{* * *}$ & $(0.032)$ & $-0.176^{* * *}$ & $(0.030)$ & $-0.280 * * *$ & $(0.049)$ \\
\hline Share of females & $-0.340^{* * *}$ & $(0.014)$ & -0.051 & $(0.062)$ & $-0.278^{* * *}$ & $(0.013)$ \\
\hline Share of migrants & $-0.080 * * *$ & $(0.026)$ & 0.060 & $(0.065)$ & -0.039 & $(0.024)$ \\
\hline Share of workers under 25 & $0.303^{* * *}$ & $(0.037)$ & -0.098 & $(0.071)$ & $0.205^{* * *}$ & $(0.035)$ \\
\hline Share of workers aged between 25 and 34 & $0.277^{* * *}$ & $(0.030)$ & -0.015 & $(0.063)$ & $0.171 * * *$ & $(0.029)$ \\
\hline Share of workers aged between 35 and 49 & $0.249 * * *$ & $(0.034)$ & 0.011 & $(0.058)$ & $0.170^{* * *}$ & $(0.032)$ \\
\hline Share of part-timers & 0.013 & $(0.042)$ & 0.067 & $(0.084)$ & 0.045 & $(0.039)$ \\
\hline Share of temporary workers & $-0.066^{*}$ & $(0.038)$ & 0.011 & $(0.035)$ & $-0.096^{* * *}$ & $(0.035)$ \\
\hline Share of blue-collar workers & $-0.615^{* * *}$ & $(0.049)$ & 0.018 & $(0.127)$ & $-0.491 * * *$ & $(0.046)$ \\
\hline Share of white-collar workers & -0.042 & $(0.052)$ & 0.100 & $(0.122)$ & $-0.175^{* * *}$ & $(0.048)$ \\
\hline Share of apprentices & $-0.945 * * *$ & $(0.065)$ & -0.106 & $(0.137)$ & $-0.813^{* * *}$ & $(0.061)$ \\
\hline Firm fixed effects & no & & yes & & no & \\
\hline Size dummies & yes & & yes & & yes & \\
\hline Year dummies & yes & & yes & & yes & \\
\hline Province dummies & yes & & - & & yes & \\
\hline Industry dummies & yes & & - & & yes & \\
\hline Year*industry dummies & yes & & yes & & yes & \\
\hline Year*province dummies & yes & & yes & & yes & \\
\hline \multicolumn{7}{|c|}{$\begin{array}{r}\text { Firm-year observations: } 27,129 \\
\text { Firms: } 5,692\end{array}$} \\
\hline
\end{tabular}

Source: VWH-AIDA data set

I compute robust standard errors for OLS and FE, and bootstrapped standard errors for ACF. For the rest, see the footnote of Table 2.

\section{Accounting for productivity levels of sending firms}

From recent studies in the literature (e.g., Serafinelli, 2019; Stoyanov and Zubanov, 2014, 2012), it has emerged that the productivity effect of hiring new workers strongly depends on the firms these new workers come from. If there is a correlation between the productivity of sending and destination firms, not accounting for the productivity of sending firms may confound regression estimates. This appendix presents the ACF-FE estimation results of a version of Equation (1), which also controls for the productivity levels of the firms the new workers come from.

The empirical procedure can be summarized as follows. First, I obtained productivity estimates of the whole sample of firms in the VWH-AIDA data set (i.e., these are the firms that can potentially be sending firms). I conducted a basic cleaning of this sample that removed firms that were closing down in the year of observation and firms for which the level of information 
from AIDA, that is, firm-level, was likely different from that in VWH, that is, establishment-level (see Appendix B, Subsection B.3). The productivity estimates for these firms are the residuals from the ACF-FE estimation of a standard value-added Cobb-Douglas production function with only labor and capital inputs and year dummies (e.g., see Devicienti et al., 2018). At this point, I matched the yearly productivity estimates of sending firms to each worker hired in the sampled firms (i.e., by the firms which constitute the original sample used in the paper's estimations). Out of the 317,096 workers hired by the sampled firms, 61,149 (i.e., 19.3\%) are matched with the productivity estimate of the sending firm. I could retrieve the identity of the sending firms for as much as 227,586 of the 317,096 (i.e., 71.8\%) workers hired by the sampled firms by using the complete VWH data set. However, in practice, I could recover productivity estimates for only a small part of the sending firms because AIDA (i.e., the data source for balance sheets) only gathers a portion of all the firms contained in VWH, as specified in Section 6 (e.g., it only gathers incorporated firms, that are non-financial, with annual sales above 500,000 thousand Euros, and for years after 1995). At this point, I computed the average productivity level of the sending firms for each firm-year observation and obtained the collapsed firm-level estimation sample. In sum, for each firm-year observation, it provides the average productivity of the firms the newly hired workers come from. ${ }^{\text {D.1 }}$ Finally, note that I was forced to drop firms experiencing no hirings, as the productivity of sending firms is a missing value for them. Moreover, I applied a minimum threshold such that the productivity level of the sending firms must be known for at least $30 \%$ of the workers hired by the firm. The rationale was to remove situations in which the average productivity of the sending firms was computed on a portion of hired workers that was too small. At the end of this procedure, there are 4,125 firm-year observations for 1,655 firms, only $15.2 \%$ of the original estimation sample. This is, in fact, the main reason why the main analysis did not control for productivity levels of the sending firms.

Table D.1 presents the results for this robustness test. The first panel shows the estimation results controlling for the productivity of sending firms, whereas the second panel presents estimation results without such control for comparative purposes (i.e., estimation of Equation (1) as in Table 2 but on the restricted sample used for this test). As one can see from the table, the estimated impacts of the different worker flows are very similar in the two specifications. This suggests that the correlation of productivity levels of sending and destination firms, which exists indeed (the coefficient associated with the productivity level of sending firms is positive and significant), does not alter regression results.

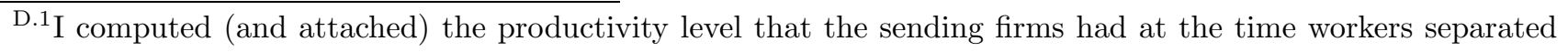
from them.
} 
Table D.1: The impact of worker flows on firm productivity: controlling for productivity levels of sending firms

\begin{tabular}{l|lr}
\hline \hline Excess worker flow rate $\left(E W F R_{i t}\right)$ & $0.064^{* * *}$ & $(0.021)$ \\
Net hiring rate $\left(N H R_{i t}\right)$ & $0.113^{* * *}$ & $(0.033)$ \\
Net separation rate $\left(N S R_{i t}\right)$ & $-0.144^{* * *}(0.045)$ \\
Productivity of sending firms & $0.027^{* *}$ & $(0.013)$ \\
\hline Excess worker flow rate $\left(E W F R_{i t}\right)$ & $0.087^{* * *}(0.031)$ \\
Net hiring rate $\left(N H R_{i t}\right)$ & $0.105^{* * *}(0.035)$ \\
Net separation rate $\left(N S R_{i t}\right)$ & $-0.190^{* *}(0.075)$ \\
\hline \hline & \multicolumn{2}{c}{ Firm-year observations: 4,125 } \\
Source: VWH-AIDA data set & Firms: 1,655 \\
Estimation method: ACF-FE. These estimates include the same set of controls of Table 2. For the rest, see \\
the footnote of Table 2.
\end{tabular}




\section{DEPARTMENT OF ECONOMICS AND STATISTICS \\ UNIVERSITY OF TORINO}

Corso Unione Sovietica 218 bis - 10134 Torino (ITALY)

Web page: http://esomas.econ.unito.it/ 